\title{
Kimberley marine biota. Historical data: echinoderms
}

\author{
Alison Sampey ${ }^{1 *}$ and Loisette M. Marsh ${ }^{1}$ \\ ${ }^{1}$ Department of Aquatic Zoology, Western Australian Museum, Locked Bag 49, Welshpool DC, \\ Western Australia 6986, Australia \\ * Email: alison.sampey@hotmail.com
}

\begin{abstract}
Australian state museums contain extensive species data and can provide baseline biodiversity information for many areas. We collated the specimen records from the Kimberley region of Australia and found 382 shallow water $(<30 \mathrm{~m})$ echinoderm species, comparable to available estimates of species richness from adjacent regions such as the Pilbara, 'Coral Triangle' or Great Barrier Reef. We identify and discuss taxonomic and collecting gaps, cross shelf patterns in species richness and composition, biogeography, and suggest some areas for future research on echinoderms in the region. At most locations, echinoderms have been incompletely sampled and many taxonomic gaps are apparent. Sampling to date has focused on hard substrates, yet there are extensive soft sediment areas in the region. More collections have occurred at inshore reefs and islands, which are more numerous, than at offshore atolls. Cumulative species richness is higher inshore than offshore, but at most inshore locations species richness is lower than offshore. However, this is biased by more collections having occurred intertidally inshore compared to subtidally offshore and much remains to be discovered about the inshore subtidal echinoderm fauna. Five times more endemic species are recorded inshore than offshore, with conservation implications. Further work is needed to identify specimens in existing collections.
\end{abstract}

KEYWORDS: natural history collections, species inventory, biodiversity, NW Australia, baseline

\section{INTRODUCTION}

The importance of utilising natural science collection datasets to provide baseline biodiversity information for conservation and environmental management decisions is now recognised (Pyke and Ehrlich 2010). The Kimberley region of Australia is currently of great interest for its conservation value with a number of proposed marine protected areas, and also for its oil and gas reserves, fishing and aquaculture activities, nature based tourism, and proposed development (Department of Environment and Conservation 2009). Consequently, baseline data to 'characterise the assets and values' in the region are needed (Wood and Mills 2008).

The Western Australian Museum (WAM) and other Australian natural science institutions have undertaken marine biodiversity surveys of the species present in the region, but much of these data and their interpretation is either unpublished or published in specialist taxonomic literature, so not readily accessible to researchers and managers. To address this data gap, WAM instigated an extensive data compilation of marine taxa known from an area henceforth titled the Kimberley Project Area (Project Area). Wilson (2014) has reviewed the historical and environmental background of the Project Area (defined below in the methods). Throughout this paper 'inshore' refers to locations along the coast, and the numerous islands and reefs found shoreward of the $50 \mathrm{~m}$ depth contour (Figure 1). 'Offshore' refers to the shelf edge atolls that rise from deeper waters (200-400 m) along the continental margin. Here, we document what is currently known about shallow water echinoderm diversity in the Project Area.

\section{ECHINODERMS}

Echinoderms are predominately marine, occasionally estuarine animals. Modern echinoderms encompass five classes, Asteroidea (sea stars), Echinoidea (urchins, sand dollars), Crinoidea (feather stars), Ophiuroidea (basket and brittle stars), and Holothuroidea (sea cucumbers). The last class includes the commercially important bêche-de-mer or trepang species, of which six species are targeted by fishers in Western Australia (Fletcher and Santoro 2010). 
Knowledge of species traits (habitat preference, feeding mode, development, spawning, settlement, and behaviour) and how these interact with biogeochemistry (temperature, salinity and oxygen) and biophysical processes (competition, predation, nutrient availability, coastal complexity, local and regional currents) is important in understanding macroecological processes (Webb et al. 2009) as well as evolution, cryptic speciation and diversity (Byrne 2006). Echinoderms inhabit soft and hard substrates and form associations with a range of sessile marine invertebrates (such as sponges, soft and hard corals and ascidians) and are hosts for an array of motile species (e.g. crustaceans, molluscs, polychaetes and fishes). They have a range of feeding strategies from predatory to scavenging (including carnivorous, herbivorous, omnivorous, microphagous, suspension and deposit feeders) and a variety of reproductive strategies (brooding, broadcast spawning, direct development and asexual reproduction by fissiparity).

Echinoderm species are known to demonstrate substantial differences in population densities, especially over decadal time scales (Uthicke et al. 2009). The crown-of-thorns sea star, Acanthaster planci is probably the best studied echinoderm species in this regard largely due to the explosion in numbers and subsequent impact on coral communities on the Great Barrier Reef. Other species are introduced marine pests. For example, the northern Pacific sea star, Asterias amurensis has caused habitat alteration and loss of native species in south eastern Australian waters. However, detection of marine pest species requires knowledge of native species (Huisman et al. 2008). Therefore, it is important to document the spatio-temporal occurrence and diversity of echinoderms.

\section{AIMS}

This paper aims to:

1. collate records of shallow water $(<30 \mathrm{~m})$ echinoderm species in the Project Area, which are verified by specimens lodged in Australian museum collections (1880s-2009) to provide a baseline diversity dataset;

2. identify taxonomic and collection bias and gaps;

3. test whether there are proportionally more wide ranging species (e.g. Indo-West Pacific or IndoPacific) occurring offshore than inshore - i.e. species that inhabit clear oligotrophic waters versus endemic or Indo-Australian species, which would have higher tolerances to the silty turbid waters occuring inshore; and

4. explore cross shelf differences in species richness and composition.

\section{HISTORY}

The earliest collections of echinoderms in the Kimberley were probably made during a French expedition led by Thomas Nicholas Baudin (18011803) on the Géographe. This expedition dredged and made a cursory survey of the coast as far north as the Bonaparte Archipelago and anchored near Cassini Island in 1801 (Marchant 1982). Regrettably, the naturalist Péron died before completing his expedition narrative and although Freycinet completed the writing of a volume of expedition notes, these did not detail what happened to all specimens collected from the region. It is likely that the echinoderms collected on this expedition were examined by Lamarck (1816) who described 20 species of echinoderms, 17 of which were Australian, other specimens were from Mauritius and 'la mer des Indies'. Unfortunately, none of these species had a precise locality recorded, as Péron's field notes were not available to Lamarck, so it is unknown if any of the specimens were collected in the Kimberley, although many of these species occur in the area.

Phillip Parker King surveyed northern Australian waters including the Kimberley between 1818 and 1822. Three species of urchins were recorded, although the precise locality of the collections was not (King 1827). Two British navy ships (H.M.S. Penguin and Egeria) passed through the Kimberley in the 1880s and some collections were made and later documented (Bell 1893, 1894) (Table 1). A new species of sea star collected at Holothuria Bank on the same expedition was later described as Gomophia sphenisci (Clark 1967).

The Swedish Mjöberg Expeditions (1910-1913) collected echinoderms off Cape Jaubert (at the northern end of 80 Mile Beach) and at Broome. Thirty nine species of echinoderms were later described from these collections by Mortensen (1918), Ekman (1918), Gislén (1919), and Döderlein (1926) (Table 1). Döderlein (1926) listed three species collected off Cape Jaubert, one of which, Tamaria pusilla, appears to have been collected from 110 $\mathrm{m}$ depth. Moreover, one of the species figured by Mortensen (1918) was Goniocidaris tubaria, a temperate species unlikely to occur in the Kimberley (the locality may have been recorded incorrectly).

The documentation of northern Australian echinoderms owes most to H.L. Clark of the Museum of Comparative Zoology at Harvard who visited Broome in 1929 for two months and again in 1932 for one month (Clark 1938). He collected intertidally, dredged in shallow waters, and obtained specimens from pearl divers between Augustus Island and 80 Mile Beach. From these collections he documented 198 species and described 71 new species (Clark 1938) of which 27 have been synonymised (Rowe and Gates 1995). 
TABLE $1 \quad$ Number of locations, species, families and classes of echinoderms sampled during main survey expeditions in the region and presented as reports. NB. * List provided for north-west Australia includes four locations, two in the Kimberley (Holothuria Bank and Baudin Island) and two in the Pilbara (Magnetic Shoal and Cossack). ${ }^{*}$ Crinoids not surveyed. ${ }^{D}$ Collections in deep waters $(>100 \mathrm{~m}) .{ }^{* *}$ WAM surveys.

\begin{tabular}{lllllll} 
Survey Year & No. Locations & No. Stations & No. Species & No. Families & No. Classes & Reference \\
\hline 1880 s? & $1 ?^{\mathrm{D}}$ & - & 2 & 2 & 1 & Bell 1893 \\
1880 s? & $4^{*}$ & - & 52 & 20 & 5 & Bell 1894 \\
1911 & 2 & - & 7 & 4 & 1 & Gislen 1919 \\
1911 & 2 & - & 13 & 8 & 1 & Mortensen 1918 \\
1911 & 2 & - & 16 & 5 & 1 & Ekman 1918 \\
1911 & 1 & - & 3 & 3 & 1 & Döderlein, 1926 \\
1929,1932 & c. 15 & - & 198 & 47 & 5 & Clark 1938 \\
1982 & 2 & 16 & 90 & 30 & 5 & Marsh 1986 \\
1984 & 2 & 23 & 117 & 35 & 5 & Marsh 1986*** \\
1986 & 2 & 24 & 178 & 37 & 5 & Marsh et. al. 1993 \\
1990 & 7 & 9 & $33+$ & 20 & 5 & Marsh 2011 \\
1991 & 25 & 34 & 82 & 29 & 5 & Marsh 1992 \\
2006 & 3 & 45 & 52 & 21 & $4^{* * * *}$ & Bryce and Marsh 2009 \\
2008 & 5 & 15 & 71 & 25 & 5 & Keesing et. al. 2011 \\
\hline
\end{tabular}

WAM surveyed six offshore atolls in the 1980s: Clerke and Mermaid Reefs, Rowley Shoals in 1982 (Marsh 1986), Scott and Seringapatam Reefs in 1984 (Marsh 1986) and Ashmore Reef and Cartier Island in 1986 (Marsh et al. 1993) (Table 1). Extensive collections were made by one of the authors (L.M. Marsh) who collected all classes of echinoderms from a variety of habitats. Species and family richness were high at all atolls, but highest at Ashmore Reef and Cartier Island (178 species; Table 1). Incidental collections of echinoderms (excluding crinoids and ophiuroids) were made at three offshore atolls (Mermaid, Scott and Seringapatam Reefs) in 2006 with 52 species from 21 families collected (Bryce and Marsh 2009).

Echinoderms were surveyed along the Kimberley coast in 1990 when the Western Australian Naturalists' Club visited Adele Island and sites around Camden Harbour (Marsh 2011). A 1991 WAM survey visited 25 locations between Broome and Wyndham and recorded 82 species from 29 families (Table 1). During both surveys, echinoderm collections were largely incidental. A recent (2008) dredging survey of the epibenthos along the Dampier Peninsula and Gourdon Bay recorded 71 echinoderm species (Keesing et al. 2011).

Based on several of these early collections, some generalisations have been suggested for the echinoderm fauna in the region. Firstly, different species occur inshore compared to offshore (Marsh and Marshall 1983). Secondly, more endemic species occur inshore compared to more widespread (e.g. Indo-West Pacific) species offshore (Marsh and Marshall 1983). Thirdly, species richness is higher offshore than inshore (Marsh 1992), although this conclusion was based on total species richness, and neither the differences between intertidal and subtidal habitats, nor unequal sampling efforts were addressed.

\section{METHODS}

The Project Area encompasses an area west and north of the Kimberley coast (south of Broome to the Western Australia-Northern Territory border) extending beyond the 1,000 $\mathrm{m}$ bathymetric contour, with the coastline forming a natural inshore boundary (Figure 1, see Sampey et al. 2014 for a full explanation of the study area). We include all five classes of echinoderms.

The methodology followed that explained in detail by Sampey et al. (2014). Briefly, echinoderm species data were sourced from the collection databases of the WAM (data extracted January 2010), the Museums and Art Galleries of the Northern Territory (MAGNT, received August 2009) and the Australian Museum (AM, received August 2009) as well as the species presented in four reports on five survey expeditions in the Kimberley (Table 1; Marsh 1986, 1992; Marsh et al. 1993; Bryce and Marsh 2009). During the review process for this manuscript a small collection of echinoderms at the Museum of Victoria (MV) was drawn to our attention. These were collected 
on a single expedition to Ashmore Reef and Johnson Bank in 2002 both intertidally and on SCUBA to depths down to $21 \mathrm{~m}$. Where possible we have incorporated these into our tables. We have included the echinoderms recorded by the Commonwealth Scientific and Industrial Research Organisation (CSIRO) survey along the Dampier Peninsula and Gourdon Bay (Keesing et al. 2011) in our species list (Appendix 2), but the numbers of specimen lots, locations, and species richness per location are not included. Many of the specimens collected by this survey, except for the Crinoidea (currently at the MV), have been deposited at WAM and are now incorporated into the collections.

Species names represent hypotheses, which are subject to change as new information (morphological, molecular, behavioural and distributional) is discovered (Gaston and Mound 1993). The species names and taxonomic placement of the records in the dataset were verified to present the currently accepted species name and resolve synonymies and old combinations, but the specimens were not re-examined (Sampey et al. 2014). Species names were checked using online databases (Appeltans et al. 2010; ABRS 2011), the Zoological Catalogue of Australia (Rowe and Gates 1995) and recent taxonomic publications.

\section{SPATIAL INFORMATION, COLLECTION DETAILS AND MAPPING}

Data from all sources were collated into a single database (Sampey et al. 2014). Location and collection details were checked and verified. The collection locations of the specimen records were visualised using ARCGIS ArcMap v9.3, outliers were examined and the latitude and longitude corrected, or the record excluded, as appropriate. Maps of species richness and sampling effort were generated for each major location. Since species richness patterns are highly dependent on sampling effort, we calculated the number of collecting events at a location to give an indication of relative sampling effort. A collecting event was defined by the season and year of collecting. The full list of locations, latitude and longitude and other relevant collection information is provided in Table 2 in Sampey et al. (2014).

\section{BIOGEOGRAPHIC AND HABITAT CODING}

Species were coded for their known biogeographic range and habitat (Table 2 and 3). Biogeography and habitat coding broadly follows the Australian Faunal Directory (AFD, ABRS 2011) and the Zoological Catalogue of Australia (Rowe and Gates 1995) for each species. Additional information for coding was derived from the distribution ranges listed by Clark and
TABLE 2

Biogeographic Codes assigned to taxa in the Kimberley Project Area.

\begin{tabular}{|c|c|}
\hline Code & Definition \\
\hline WA & $\begin{array}{l}\text { Western Australian endemic. Currently } \\
\text { known from WA waters, often only from the } \\
\text { type locality; may be a northern Australian } \\
\text { endemic with more collecting effort. }\end{array}$ \\
\hline NA & $\begin{array}{l}\text { Northern Australian endemic. Recorded in } \\
\text { tropical Australian waters. }\end{array}$ \\
\hline SA & $\begin{array}{l}\text { Southern Australian endemic. Recorded in } \\
\text { temperate Australian waters and presence in } \\
\text { the Kimberley region is the northern extent of } \\
\text { its range. }\end{array}$ \\
\hline A & $\begin{array}{l}\text { Australian endemic. Recorded in tropical and } \\
\text { temperate Australian waters. }\end{array}$ \\
\hline IA & $\begin{array}{l}\text { Indo-Australian. Recorded in Australian } \\
\text { and Indonesian waters, may extend to the } \\
\text { Philippines and Japan. }\end{array}$ \\
\hline $\mathrm{IO}$ & Indian Ocean. Restricted to the Indian Ocean. \\
\hline IWP & $\begin{array}{l}\text { Indo-West Pacific. Recorded in the Red Sea, } \\
\text { Indian and western Pacific Oceans. }\end{array}$ \\
\hline IP & $\begin{array}{l}\text { Indo-Pacific. Recorded in the Red Sea, Indian } \\
\text { and Pacific Oceans. }\end{array}$ \\
\hline WP & $\begin{array}{l}\text { West Pacific. Recorded in the western Pacific, } \\
\text { presence in the Kimberley region indicates } \\
\text { occurrence in the south eastern Indian Ocean. }\end{array}$ \\
\hline $\mathrm{T}$ & $\begin{array}{l}\text { Tropicopolitan. Recorded in all tropical } \\
\text { oceans. }\end{array}$ \\
\hline $\mathrm{C}$ & $\begin{array}{l}\text { Circumglobal. Recorded in all oceans in both } \\
\text { tropical and temperate waters. }\end{array}$ \\
\hline RS & $\begin{array}{l}\text { Red Sea. Also occurs in the Red Sea, species } \\
\text { likely needs revision. }\end{array}$ \\
\hline
\end{tabular}

TABLE 3 Habitat Codes assigned to taxa in the Kimberley Project Area.

\begin{tabular}{|c|c|}
\hline Code & Description \\
\hline i & Intertidal zone. \\
\hline s & Subtidal zone. \\
\hline $\mathrm{H}$ & $\begin{array}{l}\text { Associated with hard substrates (e.g. rock, } \\
\text { coral, rubble). }\end{array}$ \\
\hline S & $\begin{array}{l}\text { Associated with soft substrates (e.g. sand, } \\
\text { mud). }\end{array}$ \\
\hline SG & Seagrass meadows. \\
\hline EZ & $\begin{array}{l}\text { Epizoic. External association with a species } \\
\text { of animal. }\end{array}$ \\
\hline EP & $\begin{array}{l}\text { Epiphytic. External association with a species } \\
\text { of marine plant. }\end{array}$ \\
\hline $\mathrm{U}$ & Habitat of the species is unknown. \\
\hline
\end{tabular}


Rowe (1971), papers on Australian Macrophiothrix species (Hoggett 1990, 1991, 2006), and general habitat information (Coleman 2007). If a species did not conform to a single code then appropriate combinations were used.

\section{DATA ANALYSES}

A subset of the data was generated from WAM expeditions (see Table 1 and Sampey et al. 2014 for a summary) where species were recorded per station. These WAM expeditions visited inshore and offshore locations and collected intertidally at low tide by reef walking and subtidally on SCUBA. In this subset, echinoderm data were available from 45 inshore and 8 offshore locations. A 'location' is the nearest named island, reef or coastal feature, which was standardised according to the methods outlined in Sampey et al. (2014). Collection effort was variable amongst stations, expeditions and locations, which affected the calculation of species richness and distance measures, as stations with few species appear as outliers (O'Hara 2007). To address this, we followed the methods employed by O'Hara (2007) and species poor ( $\leq 5$ species) samples were removed from the dataset. All analyses were undertaken in PRIMER v6.1.11 (Clarke and Warwick 2001; Clarke and Gorley 2006).

To investigate if patterns in species richness were lower inshore than offshore and also intertidally compared to subtidally, species accumulation curves were generated in PRIMER and confidence intervals calculated (Zar, 1999).

To explore compositional differences across the shelf, the presence of species was pooled at location and then visualised using non metric multidimensional scaling (nMDS) with the Bray Curtis distance measure. The species contributing to cross shelf differences were determined using similarity percentages (SIMPER).

\section{RESULTS}

\section{NUMBER OF SPECIMENS IN COLLECTIONS}

A total of 2,761 registered specimen lots of echinoderm species were included in this dataset (Table 4). A specimen lot is one or more individuals of the same species from a single sample that has been assigned a unique registration number in a museum database. The number of lots included was variable across families, ranging from one for the Spatangidae, Caudinidae and Gorgonocephalidae to 357 for the Ophiotrichidae (Appendix 1). The number of specimen lots housed in the various institutions was also variable (MV: $96,3 \%$ of the total; AM: 374, 14\%; MAGNT: $623,22 \%$ and WAM: 1668, 61\%; Table 4).
TABLE 4 Number of registered echinoderm specimen lots from the Project Area housed in Australian museum collections. Included are those lots identified to species or Operational Taxonomic Unit and excluded are those lots incompletely identified (out of parentheses) or from deepwater $(>30 \mathrm{~m}$ ) locations (in parentheses).

\begin{tabular}{llll} 
& \multicolumn{3}{l}{ No. of Specimen Lots } \\
Collection & Included & Excluded & Total \\
\hline AM & 374 & $137(18)$ & 529 \\
MAGNT & 623 & $28(112)$ & 763 \\
WAM & 1,668 & $466(1,381)$ & 3,515 \\
MV & 96 & 4 & 100 \\
\hline Total & 2,761 & 2,146 & 4,907 \\
\hline
\end{tabular}

Many specimen lots were excluded from the present dataset (2146 lots, $45 \%$ of the total; Table 4). The majority (1511 lots) were excluded as they were collected from waters deeper than $30 \mathrm{~m}$ and so outside the scope of our study. Some of the excluded records would add extra families (and species) to our dataset, but these are known deepwater fauna that never inhabit shallow waters, e.g. Benthopectinidae (Appendix 1). The remaining lots were excluded due to incomplete or incorrect identifications where the specimens require re-identification (631 lots, 30\% of the total excluded lots).

The oldest Kimberley specimens were a heart urchin, Breynia desorii (originally identified as $B$. australiae) collected from Broome in 1913 in WAM, an urchin (Proraster jukesii) collected by H.L. Clark from Roebuck Bay in 1929 in AM and a sea cucumber (Cercodemas anceps) and a basket star (Euryale asperum) collected in 1975 from York Sound and housed in MAGNT.

In addition to collections of Kimberley specimens housed in Australian museums, the next most important collection is based on the extensive collections made by H.L. Clark in 1929 and 1932. Most of these are housed in the Museum of Comparative Zoology, Harvard (MCZH) with only a few specimens in AM and WAM.

Thirty eight of the echinoderm species collected from the Kimberley have formed the basis of new species descriptions (i.e. holotypes, paratypes and syntypes), although three of these have been synonymised (Appendix 2). For example, Archaster angulatus includes specimens originally identified and described as Archaster laevis by Clark (1938), and subsequently synonymised. Two species of crinoids, 
TABLE 5

Number of species with each biogeographic code.

\begin{tabular}{lll} 
Biogeographic Code & Inshore & Offshore \\
\hline no code & 6 & 3 \\
WA & 18 & 2 \\
NA & 31 & 8 \\
A & 5 & 3 \\
IA & 45 & 26 \\
IA/IO & 18 & 7 \\
IA/RS & 1 & 0 \\
IA/WP & 0 & 3 \\
IO & 5 & 5 \\
IP & 7 & 12 \\
IWP & 71 & 132 \\
T & 4 & 4 \\
WP & 15 & 17 \\
C & 1 & 1 \\
\hline Total & 227 & 223 \\
\hline
\end{tabular}

TABLE 6

Number of species with each habitat code.

\begin{tabular}{lll} 
Habitat Code & Inshore & Offshore \\
\hline $\mathrm{H}^{\mathrm{i}}$ & 2 & 7 \\
$\mathrm{H} / \mathrm{S}^{\mathrm{i}}$ & 0 & 4 \\
$\mathrm{H} / \mathrm{S}^{\text {is }}$ & 6 & 3 \\
$\mathrm{H} / \mathrm{S}^{\text {is }}$ & 2 & 4 \\
$\mathrm{H} / \mathrm{S}^{\text {is }} / \mathrm{SG}$ & 0 & 3 \\
$\mathrm{H} / \mathrm{S}^{\mathrm{s}}$ & 16 & 16 \\
$\mathrm{H} / \mathrm{S}^{\mathrm{s}} / \mathrm{SG}$ & 2 & 1 \\
$\mathrm{H}^{\mathrm{i}} / \mathrm{S}^{\text {is }}$ & 7 & 5 \\
$\mathrm{H}^{\mathrm{i}} / \mathrm{S}^{\text {is }}$ & 8 & 8 \\
$\mathrm{H}^{\text {is }}$ & 22 & 44 \\
$\mathrm{H}^{\text {is }} / \mathrm{EZ}$ & 1 & 2 \\
$\mathrm{H}^{\mathrm{s}}$ & 60 & 56 \\
$\mathrm{H}^{\mathrm{s}} / \mathrm{EP}$ & 0 & 1 \\
$\mathrm{H}^{\mathrm{s}} / \mathrm{EZ}$ & 13 & 14 \\
$\mathrm{H}^{\mathrm{s}} / \mathrm{S}^{\mathrm{i}}$ & 0 & 2 \\
$\mathrm{H}^{\mathrm{s}} / \mathrm{S}^{\mathrm{i}} / \mathrm{SG}$ & 0 & 1 \\
$\mathrm{H}^{\mathrm{s}} / \mathrm{S}^{\text {is }}$ & 1 & 4 \\
$\mathrm{~S}^{\mathrm{i}}$ & 2 & 2 \\
$\mathrm{~S}^{\mathrm{i}} / \mathrm{SG}$ & 1 & 1 \\
$\mathrm{~S}^{\text {is }}$ & 15 & 9 \\
$\mathrm{~S}^{\text {is }} / \mathrm{SG}$ & 1 & 0 \\
$\mathrm{~S}^{\mathrm{s}}$ & 61 & 33 \\
$\mathrm{U}$ & 7 & 3 \\
\hline Total & 227 & 223 \\
\hline
\end{tabular}

Toxometra lepta and T. poecila collected by H.L. Clarke near Broome are not included in our species list as the types are housed in MCZH collections, which were not searched for this study as only data obtained from Australian museum collections were included (see Methods above and Sampey et al. 2014 for full justification). Our list includes species remaining to be described e.g. Protankyra sp. nov. 1 (Appendix 2).

\section{SPECIES RICHNESS AND COLLECTING EFFORT}

We recorded a total of 382 echinoderm species from 54 families (Appendix 2). This included 71 species of Asteroidea, 51 species of Crinoidea, 58 species of Echinoidea, 91 species of Holothuroidea, and 111 species of Ophiuroidea. In addition, are three crinoid species recorded previously from the area and not included in our dataset; T. lepta and T. poecila recorded by Clark (1938), and Phanogenia typica recorded by Gislén (1919) from Cape Jaubert (as Comaster typica) taking the total number to 385 species.

A number of species are known only from the type material, for example, Anthenoides dubius H.L. Clark, 1938, was collected between Lagrange Bay and Broome in 10-37 m of water. The types are lodged in MCZH and AM and the species has not been collected since.

Echinoderm data are available for 93 locations in the Kimberley (Appendix 3, Figures 1-3), and Johnson Bank $\left(12.37367^{\circ} \mathrm{S} 123.26833^{\circ} \mathrm{E}\right)$; MV collections are not incorporated into the figures). Species richness ranged from 173 at Ashmore Reef to one at 15 inshore locations. Collecting effort was also variable, ranging from 41 collecting events at Broome to one at 48 locations. The number of families collected at any one location was also variable with 41 families collected at Broome compared to only one family at 17 locations. Cumulatively, more species have now been recorded inshore than offshore (227 versus 223 species; Tables 5, 6, Appendix 2), but collecting effort is also higher inshore than offshore (90 versus 15 collecting events). No collecting has occurred at Browse Island (midshelf), Hibernia or Imperieuse Reefs. Only three locations in the eastern Kimberley have been sampled for echinoderms.

Although the total cumulative number of species is higher inshore than offshore this is not the case for individual locations. Generally, species richness recorded from any inshore location (except for Broome) is lower than that recorded offshore. For example, Ashmore Reef had the highest species richness of the offshore locations (173 species), which was similar in species richness to Broome (167 species). However, the collecting effort at Broome was much higher (41 collecting events) than at Ashmore Reef (8 collecting events). 
With similar sampling effort, species richness was substantially higher offshore than inshore for the intertidal stations and the combined dataset (Figure 4). For subtidal stations, this pattern was much less clear. To date, only 20 subtidal stations have been sampled inshore, providing a total species richness of 60 . The total species richness for the subtidal stations offshore was substantially higher (144 species from 70 stations). The species accumulation curves for subtidal habitats inshore and offshore are closer than for either intertidal or the combined stations. Species richness values were only slightly higher offshore than inshore for comparable sampling effort (20 stations offshore had 76 species versus 60 species inshore), and the confidence intervals of the data overlap. There has been more sampling effort in the intertidal inshore compared to offshore (42 versus 31 collecting events respectively). In the subtidal there has been little collecting effort inshore compared to offshore (20 versus 70 collecting events, respectively; Table 5).

Multivariate species composition patterns show a clear division offshore compared to inshore, both intertidally and subtidally (only the combined assemblages shown; Figure 4), with an average dissimilarity of $94 \%$. The offshore locations are more tightly clustered indicating a higher degree of similarity (average similarity 52\%) in assemblage composition offshore compared to the inshore locations (average similarity 14\%). This is in part a function of the lower numbers of echinoderm species inshore compared to offshore, but also due to the variety of habitats sampled inshore compared to offshore. Moreover, some species have been found only inshore while others occurred only offshore, e.g. Phyllacanthus longispinus inshore and the common coral reef sea star, Linckia laevigata offshore (Appendix 2). Some of these differences may be due to a sampling artefact, but they agree with the currently known Australian distributions of the species.

Several species pairs of the same genus exemplify the inshore versus offshore division in species composition. Protoreaster nodulosus (Perrier, 1875) is an inshore endemic species found only from the Houtman Abrolhos to Admiralty Gulf, while P. nodosus (Linnaeus, 1758) is widespread from Queensland throughout the Indo-West-Central Pacific, and in Western Australia has been recorded only from Ashmore Reef (Appendix 2).

\section{BIOGEOGRAPHY AND HABITATS}

The majority of species at both inshore and offshore locations were widespread species (all categories C, IO, IP, IP/AT, IWP, T, WP; see Table 2 for definitions), with 102 species inshore compared to 167 offshore (Table 5). However, the proportion of widespread species was higher offshore than inshore $(77 \%$ of the total versus $45 \%$, respectively; Table 5). By comparison, the proportion of endemics (categories WA, NA, and A) inshore was almost five times the proportion of endemics offshore (54 species, $24 \%$ of total versus 12 species, $5 \%$, respectively; Table 5). The proportion of IndoAustralian species was also higher inshore than offshore (45 species, $19 \%$ versus 24 species, $11 \%$, respectively; Table 5).

A high proportion of the species were associated with hard substrates, 140 species (62\%) inshore, compared to 169 species (78\%) offshore for all combinations. Some of the species associated with hard substrates were also associated with soft substrates; these were generally reef associated species occurring in sand pockets either on or close to the reef or under rocks. However, some species were associated only with soft substrates (80 species, 35\% inshore versus 44 species, 20\% offshore; Table 6). Twenty four species were epizoic (EZ), but these were in similar numbers and proportions inshore and offshore (14 species, $6 \%$, versus 16 species, $7 \%$, respectively; Table 6 , Appendix 2). Only a single species, Ophiocomella sexradia, was associated with marine plants, but this species is also found under rock slabs (Appendix 2).

\section{DISCUSSION}

We have provided a broad summary of the cumulative knowledge of echinoderm diversity from the Kimberley Project Area based primarily on museum collection and survey data. These qualitative datasets are irreplaceable for providing species inventories of an area (Mikkelsen and Cracraft 2001). Many species of echinoderms cannot be identified in the field as they require microscopic examination. This needs taxonomic expertise, access to specialised literature, and previously (and accurately) identified specimens, which are all available at natural science museums. Hence, the diversity of echinoderms known from many regions under the jurisdiction of museums will be well represented in these collections. All the recent collections from the Project Area have resulted in new species and range extensions (Marsh 1986, 1992; Marsh et al. 1993; Bryce 2009; Keesing et al. 2011; Marsh 2011). This is expected to continue as the region has a high diversity of habitats and remains remote and under sampled.

To date, collecting focus in the Kimberley Project Area has been the generation of species inventories for the locations sampled. Although data from some expeditions were presented in reports with species listed per station, which facilitated statistical analysis, some caveats must be made. Firstly, these data can be considered to be presence only, with absences implied. This limits the analyses able to be undertaken using software such as PRIMER, 
where comparable sampling effort is an implicit assumption. Secondly, collecting effort (spatial, temporal and taxonomic) across locations is highly variable and this has potentially influenced the observed patterns. We attempted to reduce this variability in our analyses by removing species poor samples and by using species accumulation curves to explore species richness patterns.

\section{SPECIES RICHNESS PATTERNS}

Our combined dataset provides records of 382 shallow water echinoderm species for the Project Area. This is higher than the 286 species recorded for the Dampier region (Marsh and Morrison 2004), which was derived from a comprehensive assessment of the habitats in the Dampier Archipelago utilising intertidal, diving and dredging surveys over two years, and supplemented with database records of historical collections. Endean (1957) reported 267 species of shallow water echinoderms (excluding crinoids) from Queensland. Although this estimate is lower than our Kimberley estimate, it is fifty years old. There have been more recent publications describing new species from the Great Barrier Reef (e.g. O'Loughlin and Rowe 2006), but none provided a summary of the echinoderm biodiversity in the area. We recorded 91 species of holothurians in this dataset, which is higher than the 56 species reported for the Spermonde Archipelago, Indonesia (Massin 1999) at the centre of the 'Coral Triangle', a known centre of maximum marine biodiversity (Hoeksema 2007). Due to the vastly different sampling efforts (spatial and temporal) of each study it would be misleading to claim echinoderm species richness is greater in the Kimberley than in these areas, but it appears to be comparable. This could in part be explained by the proximity of the Kimberley to these other regions and the potential connectivity via regional currents (e.g. Indonesian Throughflow, Marsh 1976; Marsh and Marshall 1983; Marsh et al. 1993) and planktonic larval duration (e.g. hours to months, Yamaguchi and Lucas 1984).

Our cumulative species richness estimates for inshore are slightly higher than for offshore (227 versus 223). However, at any one location species richness was generally lower inshore than offshore. This pattern was obvious in the intertidal locations and may be due to the harsh environment inshore (tidal exposure, siltation and seasonal flood plumes).

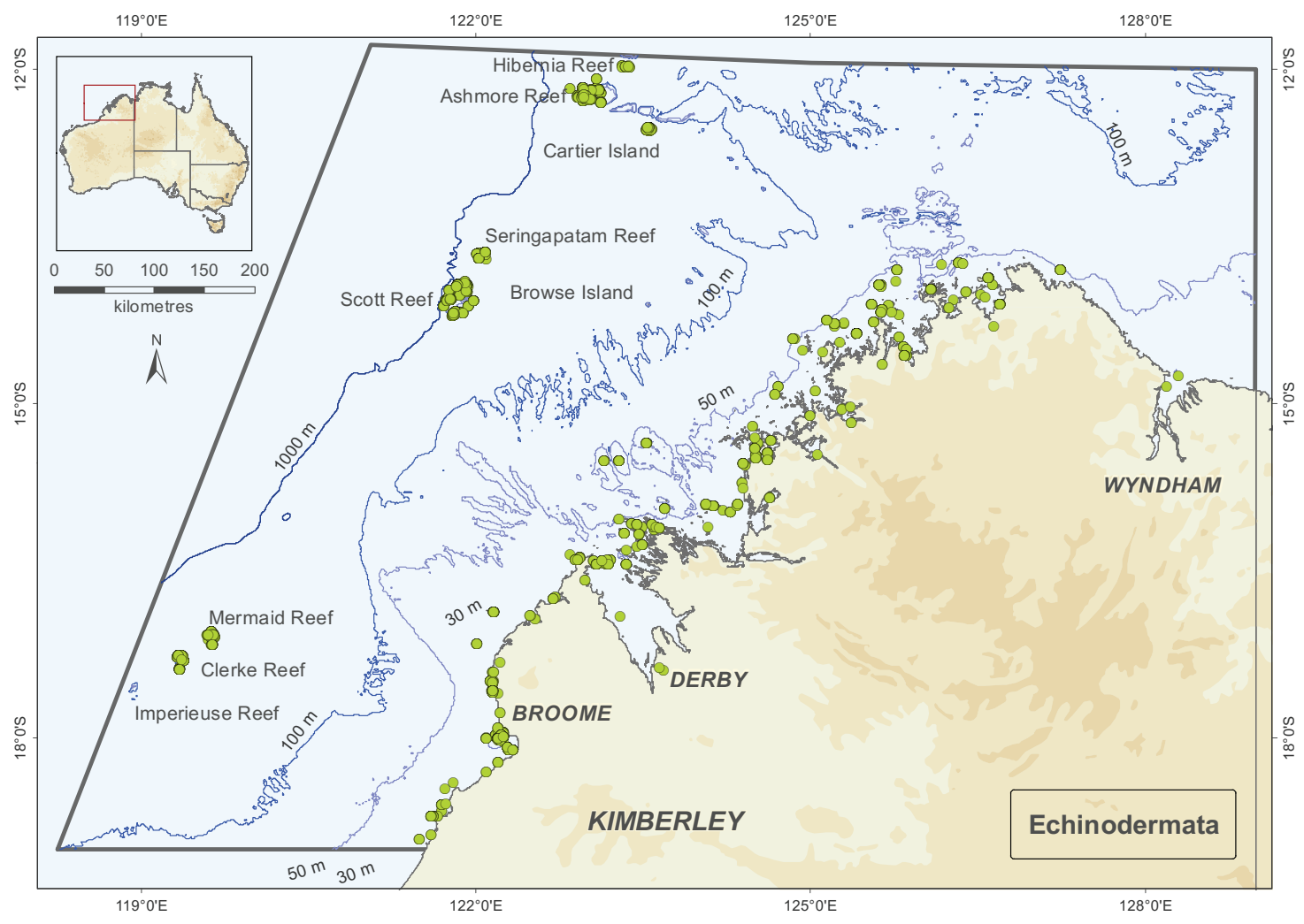

FIGURE 1 Location of historical records of echinoderms in the Kimberley Project Area of Western Australia. The Project Area boundary is marked in grey. Map projection: GDA94, Scale: 1:6, 250,000. 


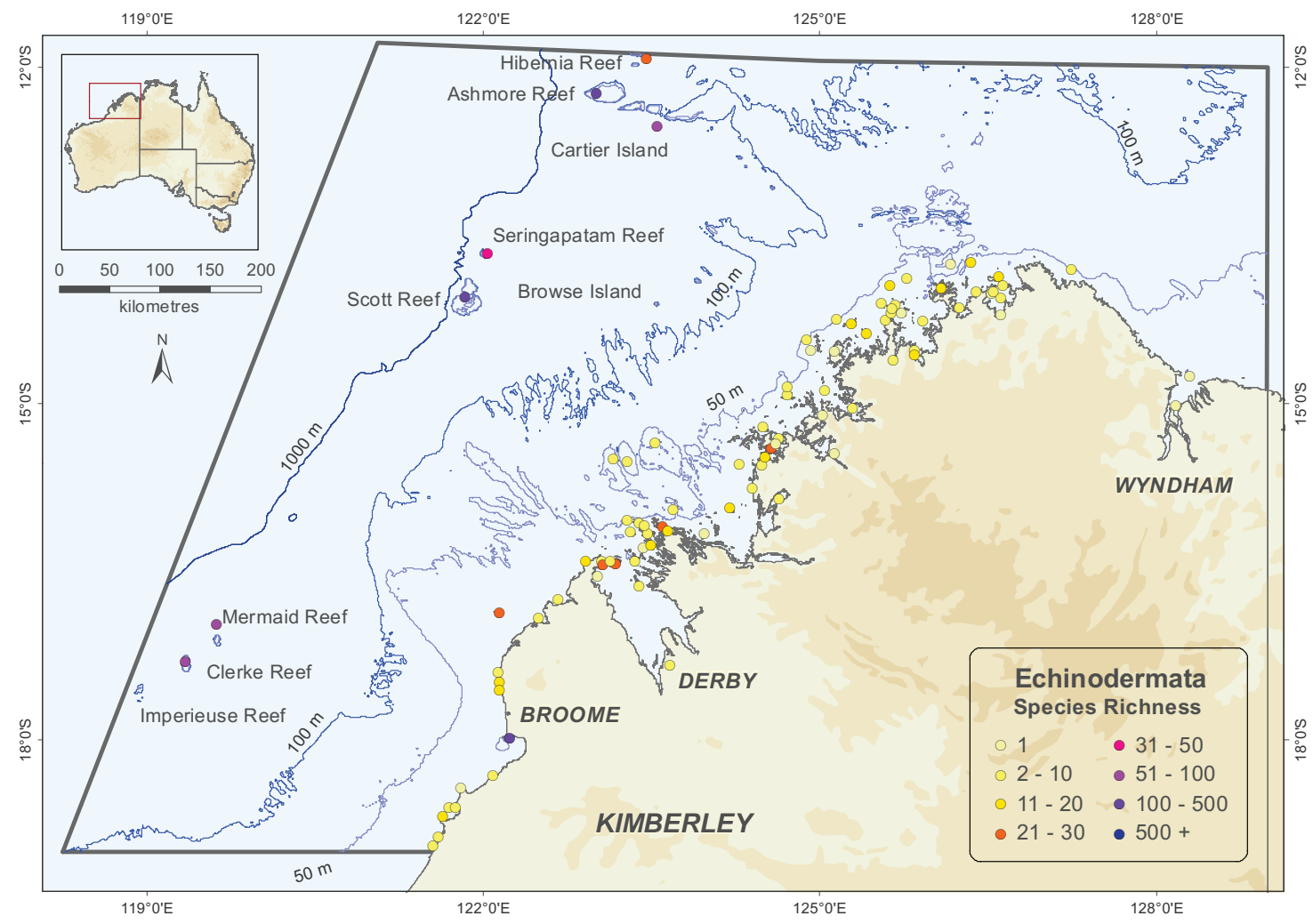

FIGURE 2 Species richness of echinoderms for each location. Map projection: GDA94, Scale: 1:6, $250,000$.

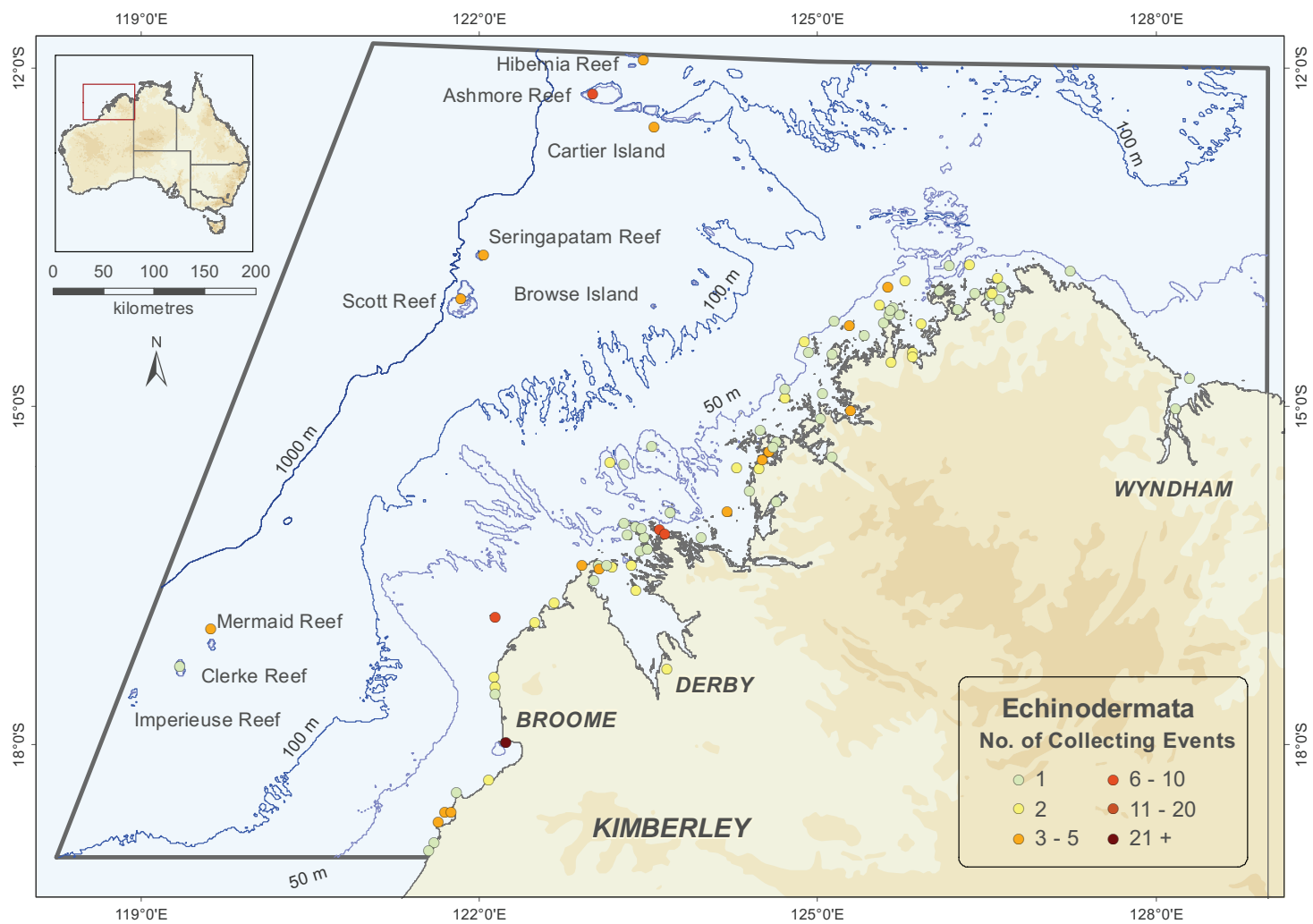

FIGURE 3 Number of collecting events for echinoderms at each main location for which there are collections. This was based on a count of the season code and provides an indication of sampling effort. Map projection: GDA94, Scale: 1:6, 250,000. 
Echinoderms are a predominately marine phylum and most species do not tolerate extremes of salinity (Stickle and Diehl 1987) so only a few species are likely to inhabit such intertidal areas. For the subtidal stations inshore and offshore, differences in species richness were smaller. Thus, it appears species richness is not necessarily consistently lower inshore compared to offshore locations, but may have been influenced by the limited sampling from subtidal areas in the inshore Kimberley to date.

Species richness patterns across locations for the most part reflect the variable collection effort and should not be interpreted as an accurate measure of species richness, especially when it is the result of a single collecting event. However, this data presentation has allowed an assessment of surveyed locations and identified gaps in the available data.

\section{COLLECTION GAPS}

A number of collecting gaps have been identified in this dataset: location, habitat, which is also linked to the collecting method used and taxonomic. In our dataset there were no echinoderm data available from the midshelf and two of the offshore atoll locations (Hibernia and Imperieuse Reefs). The eastern Kimberley was also poorly surveyed with only a single echinoderm species recorded from three locations along this section of coastline. Contemporary surveys undertaken by WAM as part of the Woodside Collection Project (Kimberley) 2009-2014 have targeted specific locations through the Project Area and these will address some of the location gaps identified, including the lack of data from midshelf locations and some of the offshore atolls e.g. Imperieuse and Hibernia Reefs. However, the eastern Kimberley remains under sampled and this region also contains extensive soft sediment habitat (Wilson 2013).

The majority of the surveys from which this dataset has been derived collected fauna by hand on reef walking and diving surveys, so collecting methodology was limited. The Project Area encompasses a wide range of habitats including mangroves, seagrass beds, coral reefs, intertidal sand and mud flats, filter feeder, and subtidal soft sediment habitats. The habitat coding of the species in our dataset provides some indication of the habitats sampled to date, which are predominantly hard substrates. Yet extensive soft substrate habitats occur in the region and recent sampling using an epibenthic sled indicates that the subtidal echinoderm communities (10-25 $\mathrm{m})$ may be diverse and some species in high abundance (Keesing et al. 2011). One of the authors (L.M. Marsh) has observed this at some locations (e.g. Prince Frederick Harbour) where the subtidal habitats were exposed at an extreme low spring tide revealing a rich filter feeder community with many coral and echinoderm species. The difficulties of sampling these subtidal habitats in the remote Kimberley will require different collecting methods. The macro-tides, turbid waters, crocodiles and sharks will necessitate different collecting methods other than intertidal and diving surveys utilised so far, to adequately sample echinoderm diversity in the region.

On many expeditions to the Project Area, echinoderms were collected only incidentally (1988, 1994, 1995, 1996, 1997), or collected in conjunction with other taxa $(1991,2006)$. Only on the earlier

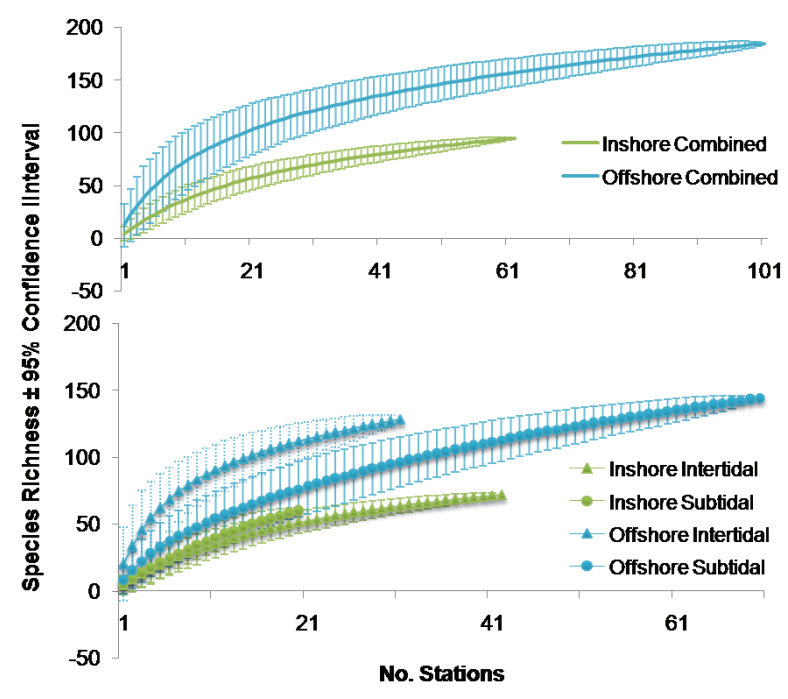

FIGURE 4 Species accumulation curves for the Western Australian Museum surveys.

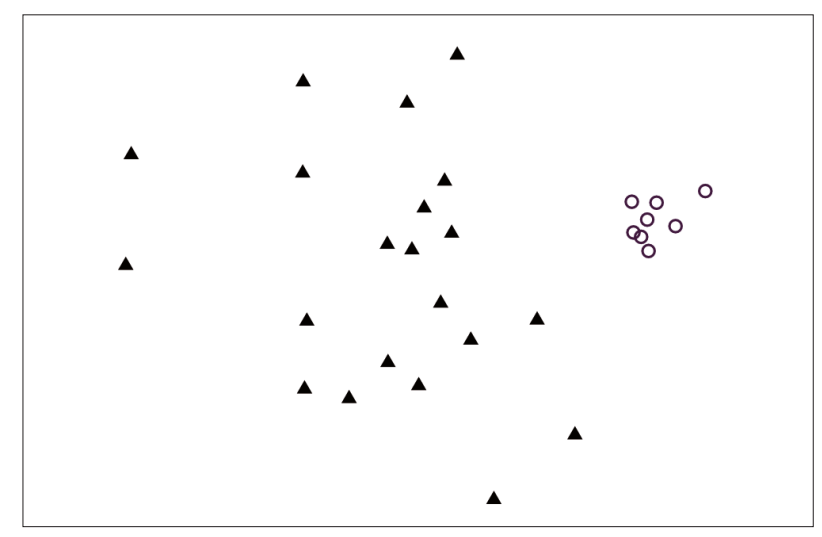

FIGURE 5 Ordination (nMDS) based on Bray-Curtis Similarity of the presence of echinoderm species. Each symbol represents a single location, inshore $(\mathbf{\Delta})$, offshore (o). Twodimensional stress 0.18 . 
offshore atolls surveys (Ashmore 1986, Rowley Shoals 1982 and Scott/Seringapatam 1984) did echinoderms have a specialist allocated for their collection and field preservation. The benefits of this are illustrated by the higher numbers of species recorded. Much of the diversity of echinoderms will be generated from intensive collections of an array of habitats (primarily sessile invertebrates) where small cryptic species reside, and these will be overlooked unless specifically targeted.

\section{TAXONOMIC GAPS}

Taxonomic biases in a dataset arise due to collecting partiality (e.g. a collector may target only certain groups and hard-to-collect species will be under represented) and identification partiality (e.g. easily identified and taxonomically resolved species or species of particular interest to a taxonomist will be over represented). To date, Kimberley echinoderm collections have focussed on large, visually apparent species including commercially important sea cucumber species. The most frequently collected family in our dataset was Holothuriidae, collected from 39 of the 91 locations surveyed. These are easy to collect, but require microscopic examination of spicules to obtain accurate identification. By comparison, species of sea urchin in the Diadematidae can readily be identified in the field, but are difficult to collect as they live in crevices and have toxic spines (Marsh and Slack-Smith 2010). These urchins were collected from 19 of the 91 locations in our dataset. When utilising museum data to inform conservation decisions, consideration needs to be given to taxonomic biases in the collecting of the data as this can impinge on interpretations of the biodiversity of an area and any comparisons to other areas.

Some families were inconsistently present across locations, for example, many species of Amphiuridae have been collected at inshore than offshore locations. Many amphiurids are associated with macroalgae, rubble or soft sediment (i.e. infauna) (Marsh and O'Hara, personal observation) so the apparent paucity offshore will be due partly to limited sampling of suitable habitat. However, macroalgal diversity offshore is lower than inshore (Huisman et al. 2009) so lack of suitable habitat may also have contributed to this pattern.

\section{CROSS SHELF AND ALONG SHELF PATTERNS IN SPECIES COMPOSITION}

In general, the inshore is a turbid silty environment, with freshwater runoff and input of nutrients particularly during the summer wet season (Brocx and Semeniuk 2011) compared to the clear oligotrophic waters offshore (Collins 2011). These differences are likely to have contributed to cross shelf differences in echinoderm species assemblages. Our data clearly show that species richness and composition differ inshore compared to offshore. Many echinoderms cannot live in low salinity or very turbid and silty environments which could affect larval settlement and recruitment as well as adult feeding and reproduction. However, some species can tolerate such environments: e.g. Amphipholis squamata has been reported to tolerate salinity as low as 5\% (Stickle and Diehl 1987). This species has been found at both inshore and offshore locations in the Project Area, but shown to contain divergent lineages that may represent a suite of cryptic species ( $\mathrm{O}^{\prime}$ Hara, personal communication).

The degree of silt and turbidity also varies within the inshore Kimberley. For example, Hutchins (1999) reported three assemblages of fishes along the coast and suggested that these compositional differences may be related to different degrees of turbidity. Two major coastal morphological and botanical boundaries have been suggested for the Kimberley coastline, one at Cape Leveque (SW of King Sound) and one at Cape Rulhiers (NE tip of the Kimberley Coast), both of which are associated with major river outflows (Semeniuk 1993; Brooke 1996; Hutchins 1999). Currently, we do not have enough echinoderm data for all sections of the coastline to make such a comparison. However, the sand dollar Arachnoides tenuis, a Western Australian endemic species occurs south from Cape Leveque to Shark Bay. It is replaced north of King Sound by $A$. placenta, a widespread east Indo-West Pacific species (ABRS 2011), suggesting a transition from one faunal zone to another. This warrants further investigation with targeted surveys in the region.

\section{REGIONAL BIOGEOGRAPHY AND ENDEMISM}

Regionally, the Project Area represents an overlap zone of fauna and our synthesis shows species with different biogeographic ranges (NA, IA, IO, WP, IWP, C; Table 2) co-occurring in the region. North-west Australia represents the western range limit of Western Pacific species, the eastern limit of a few primarily Indian Ocean species and the southern limit of Indo-Malayan species. An analysis of the zoogeography of north-west Australian echinoderms (other than holothurians) by Marsh and Marshall (1983) included data from the Rowley Shoals and Seringapatam Reef and concluded that the fauna of the offshore shelf edge atolls consisted of widespread Indo-West Pacific species while the coastal and shelf echinoderm fauna had a greater proportion of endemics and species with Indo-Malayan affinities. Our synthesis confirms and reinforces these conclusions.

We determined that rates of regional endemism for the echinoderms inshore are more than five 
times those offshore ( $25 \%$ versus $5 \%$, respectively) and greater than the level reported for the South China Sea (12\%, Lane et al. 2001). The Kimberley coast encompasses a range of geological features (sandstones, basalts, sedimentary and metamorphic rocks), coastline morphology (cliffs, bays, mesas, rias, mudflats and beaches), rainfall (humid, subhumid and semi-arid), and is influenced by local and regional water movement (tides, currents, river outflows) (Brocx and Semeniuk 2011). These all influence the diversity of habitats and their proximity to each other, regional connectivity through currents, larval life history and speciation processes. In summary, the high levels of endemism inshore reported here were expected.

Accurate assessments of endemism require that all specimens collected from a region are fully identified and extensive sampling of suitable habitats in adjacent regions is undertaken to determine distributions. This is not yet the case for the Kimberley or adjacent regions. For example, Echinaster superbus was collected and described by Clark (1938) and until relatively recently was known only from the type locality of Broome. Recent collecting has recorded this species as far south as Dampier (Marsh and Morrison 2004). Furthermore, many of the endemic species on our list have a wide range (NA) and collections are needed that cover locations across northern Australia to clarify species ranges, although the eastern and western limits of many NA endemic species are known (Rowe and Gates 1995). For some species there is relatively little character variation throughout their range (e.g. Stellaster princeps), while for others (e.g. Anthenea conjungens and Goniodiscaster acanthodes) there is clinal variation in characters across their range blurring the distinction between species. This could be elucidated by DNA studies where cryptic species can be identified. For example, Anthenea spp. and Goniodiscaster spp. are large and conspicuous, and commonly picked up by prawn trawlers so potentially material is readily available to examine these possible species complexes.

High degrees of endemism pose problems for conservation strategies; an understanding of the biology of a species is required to determine which species are important for conservation purposes and whether endemic species play a more important role in the ecosystem than other species (Gray 1997). Endemic species are generally those with particular life history traits (e.g. restricted habitat requirements, a brooding or direct development larval strategy) (Jones and Kaly 1995; O'Hara 2002). For echinoderms these types of larval life strategies are more prevalent in temperate water species (O'Loughlin 1991), but see Byrne (2006) for some tropical examples. Studies on the biology of tropical species are limited and have usually been restricted to widespread, larger bodied, visually apparent species, such as Acanthaster plancii or the commercial sea cucumber species. Thus, not only are the species occurring in the region poorly surveyed throughout their range, but their biology is completely unknown. More research is needed on the biology of selected species, encompassing a range of life history strategies, to aid the interpretation of species lists and inform conservation decisions.

\section{CONCLUSIONS AND FUTURE DIRECTIONS}

This synthesis has clearly shown that the Kimberley echinoderm fauna is speciose and encompasses species with a range of distributions. So far, collections in the region have focussed on reef associated species and the soft sediment and deepwater fauna remains poorly documented and described. Moreover, we restricted our dataset to shallow water species $(<30 \mathrm{~m})$ for reasons outlined in Sampey et al. (2014), but we recognise there is an extensive deeper water fauna. At least two major expeditions have undertaken sampling from the deeper (30-200 m) shelf waters in the region, the Soela (1979-1984) and the Southern Surveyor (2007). The fauna are housed in WAM and MV collections, but remain incompletely identified and contain undescribed species. This synthesis is a first step in utilising museum data and further research should include re-examination of existing specimens, genetic studies, bioregional analyses of selected taxa, and release of these data to online databases to facilitate utilisation by managers and other researchers. We have identified collection and taxonomic gaps in the data to guide further study.

A lack of echinoderm taxonomists in Australia is a major hindrance to the documentation of the fauna. Currently, there is only one full time echinoderm taxonomist in an Australian museum (MV) and much of the research is undertaken by retired taxonomists, students or early career taxonomists funded from external grants. A number of the specimens in our dataset were not incorporated into our species list due to taxonomic uncertainty. This was due to incomplete identification, taxa that are unresolved taxonomically and species that have undergone recent revisions, either purely morphological (e.g. Rankin and Messing 2008) or those utilising molecular and morphological data (e.g. O'Loughlin and Waters 2004; Mah and Foltz, 2011) resulting in revised species concepts. Examination of specimens is required to resolve species level identifications across multiple collecting events. 
Classical taxonomy focussed on morphological characters and the advent and rapid advancement of genetic techniques has led to many projects questioning species concepts (e.g. Acanthaster planci, Vogler et al. 2008). To date, no genetic material of echinoderms from the Project Area has been analysed. Historically all echinoderms, except holothurians, were preserved in formalin and not suitable for genetic studies. All specimens collected on two contemporary expeditions $(2009 / 2010)$ were preserved in high grade ethanol to facilitate genetic studies and this will be an ongoing practice. Genetic studies need to be undertaken in conjunction with morphological studies and cannot be used in isolation from classical taxonomic practice (DeSalle et al. 2005). Integrative taxonomic approaches (utilising DNA, morphological, geographical, reproductive, ecological and behavioural data) for a species are needed so taxonomy can move beyond pattern description to consider the processes underpinning speciation (Padial et al. 2010).

A current area of research utilising museum data is to explore large scale bioregional comparisons (e.g. O'Hara and Poore 2000; Graham et al. 2004; Hooper and Ekins 2004; Fox and Beckley 2005; Harnik 2009; Hoeksema et al. 2011; O'Hara et al. 2011). Our compilation of species from the Project Area is based primarily on specimen records (presence data). We have not listed species likely to occur in the region based on known species ranges. These would need to be incorporated to complete the dataset. Additionally, many species are too rare or cryptic to be adequately sampled across the whole region or have not been surveyed due to taxonomic or collection biases. Model taxa suitable for further analyses require identification to investigate connectivity. These need to be taxonomically resolved and well surveyed throughout their habitat and biogeographic range (Hoeksema 2007). In our dataset three families, Holothuriidae, Ophiotrichidae, and Oreasteridae were more consistently collected across locations. These encompass three classes of echinoderms with an array of life history strategies and would be a starting place to find species that have been adequately sampled across the region. It is imperative that museums and taxonomists are consulted and act as collaborators of projects to identify suitable taxa for further study.

Species richness is a useful biodiversity measure, but it is heavily influenced by sampling effort and scale of interpretation. It is important to present species richness summaries at a scale that is biologically meaningful, but also has relevance to managers. This is in part illustrated by our cross shelf comparisons of species richness (total versus intertidal versus subtidal versus location) and when comparing species richness values to other studies. Further work is needed to both consolidate and make accessible data in standardised, centralised databases so that meaningful summaries can be generated in a manner relevant to research or management questions.

In conclusion, priorities for future research in the region are:

- Collate the deepwater species data from the region (requires collaboration between WAM, MV, CSIRO and AIMS who hold relevant datasets)

- Undertake a survey program in the eastern Kimberley. This will address spatial, habitat and bioregional gaps in the data, and inform interpretation of endemic species ranges.

- Utilise additional survey methodologies (e.g. trawls and epibenthic sleds) to more fully describe the diversity of the region.

- Further taxonomic research on material already held in collections including genetic research.

- Analysis of the data using mathematical models (e.g. Elith et al. 2006) and bioregional analyses (e.g. O'Hara et al. 2011) with a focus on the Holothuriidae, Ophiotrichidae and Oreasteridae as these families were more consistently collected across locations and are reasonably well resolved taxonomically.

\section{ACKNOWLEDGEMENTS}

Over the years, many volunteers, museum staff members and international taxonomic experts have contributed to the collection, identification and maintenance of these datasets. We cannot list everyone involved, but we recognise their valuable contribution. Particular recognition and thanks to Stacey Osborne and Albert Miles for tirelessly databasing the unregistered Kimberley material in WAM collections, and their assistance with checking taxonomic and spatial information. Additional thanks to Stacey Osborne for formatting tables for this paper. Thanks to Piers Higgs, Anthony Jones, Andrew Denison, Kehan Harman, Akeal Hayak and Ben Zehan at Gaia Resources for database and GIS support. Many thanks to Jane Fromont, Sue Morrison and Glenn Moore for their helpful comments and discussions on this manuscript. Thanks to Tim O'Hara and John Keesing for their review of the manuscript and their positive and constructive comments. 


\section{REFERENCES}

ABRS (2011). Australian Faunal Directory. Australian Biological Resources Study: Canberra, Australia; http://www.environment.gov.au/biodiversity/abrs/ online-resources/fauna/afd/index.html. Accessed 2008- 2011.

Appeltans, W., Bouchet, P., Boxshall, G.A., Fauchald, K., Gordon, D.P., Hoeksema, B.W., Poore, G.C.B., van Soest, R.W.M., Stöhr, S., Walter, T.C. and Costello, M.J. (eds) (2010). World Register of Marine Species. online at http://www.marinespecies.org. Accessed 2008-2011.

Bell, F.J. (1893). On a Small Collection of Crinoids from the Sahul Bank, North Australia. Journal of the Linnean Society (Zoology) 24: 339-341.

Bell, F.J. (1894). On the echinoderms collected during the voyage of HMS Penguin and by HMS Egeria, when surveying Macclesfield Bank. Proceedings of the Zoological Society of London 1894: 392-413.

Brocx, M. and Semeniuk, V. (2011). The global geoheritage significance of the Kimberley Coast, Western Australia. Journal of the Royal Society of Western Australia 94(2): 57-88.

Brooke, B. (1996). Part 4. Geomorphology of the Northern Kimberley Coast (pp. 11-35). In Survey of the Marine Biota of the Eastern Kimberley, Western Australia. Unpublished Report. Western Australian Museum: Perth.

Bryce, C.W. (ed.) (2009). Marine biodiversity survey of Mermaid Reef (Rowley Shoals), Scott and Seringapatam Reef. Records of the Western Australian Museum. Supplement 77. Western Australian Museum: Perth.

Bryce, C.W. and Marsh, L.M. (2009). Echinodermata (Asteroidea, Echinoidea and Holothuroidea) of Mermaid (Rowley Shoals), Scott and Seringapatam Reefs, Western Australia. Records of the Western Australian Museum Supplement 77: 209-220.

Byrne, M. (2006). Life history diversity and evolution in the Asterinidae. Integrative and Comparative Biology 46(3): 243-254.

Clark, A.M. (1967). Notes on Asteroids in the British Museum (Natural History) V. Nardoa and some other ophidiasterids. Bulletin of the British Museum (Natural History) Zoology 15(4): 1-198.

Clark, A.M. and Rowe, F.W.E. (1971). Monograph of shallow-water Indo-West Pacific echinoderms. Trustees of the British Museum (Natural History): London, UK.

Clark, H.L. (1938). Echinoderms from Australia: an account of collections made in 1929 and 1932. Memoirs of the Museum of Comparative Zoology at Harvard College 55.

Clarke, K.R. and Gorley, R.N. (eds) (2006). PRIMER v6: user manual/tutorial. Unpublished Report. PRIMER-E: Plymouth, United Kingdom.

Clarke, K.R. and Warwick, R.M. (eds) (2001). Change in Marine Communities: An Approach to Statistical Analysis and Interpretation. 2nd edition. Unpublished Report. PRIMER-E: Plymouth, United Kingdom.

Coleman, N. (2007). Sea stars. echinoderms of the Asial Indo-Pacific. identification - biodiversity - zoology. Neville Coleman's Underwater Geographic: Springwood, Australia.
Collins, L.B. (2011). Geological setting, marine geomorphology, sediments and oceanic shoals growth history of the Kimberley Region. Journal of the Royal Society of Western Australia 94: 89-105.

Department of Environment and Conservation (2009). Protecting the Kimberley. A synthesis of scientific knowledge to support conservation management in the Kimberley region of Western Australia. Unpublished Report. Department of Environment and Conservation: Perth.

DeSalle, R., Egan, M.G. and Siddall, M. (2005). The unholy trinity: taxonomy, species delimitation and DNA barcoding. Philosophical Transactions of the Royal Society B: Biological Sciences 360(1462): 1905-1916.

Döderlein, L. (1926). Über asteriden aus dem museum von Stockholm. Kunglia Svenska Vetenskapsakademiens handlingar 2(6): 3-22.

Ekman, S. (1918). Results of Dr. E. Mjöberg's Swedish scientific expeditions to Australia 1910-1913. Part XIX. Holothuriodea. Kunglia Svenska Vetenskapsakademiens handlingar 58(6): 1-70.

Elith, J., Graham, C.H., Anderson, R.P., Dudík, M., Ferrier, S., Guisan, A., Hijmans, R.J., Huettmann, F., Leathwick, J.R., Lehmann, A., Li, J., Lohmann, L.G., Loizelle, B.A., Manion, G., Moritz, C., Nakamura, M., Nakazawa, Y., Overton, J.M., Peterson, A.T., Phillips, S.J., Richardson, K., Scachetti-Pereira, R., Schapire, R.E., Soberón, J., Williams, S., Wisz, M.S. and Zimmermann, N.E. (2006). Novel methods improve prediction of species' distributions from occurrence data. Ecography 29: 129-151.

Endean, R. (1957). The biogeography of Queensland's shallow-water echinoderm fauna (excluding Crinoidea), with a rearrangement of the faunistic provinces of tropical Australia. Australian Journal of Marine and Freshwater Research 8: 233-273.

Fletcher, W.J. and Santoro, K. (eds) (2010). State of the Fisheries and Aquatic Resources Report 2009/10. Unpublished Report. Department of Fisheries: Perth.

Fox, N.J. and Beckley, L.E. (2005). Priority areas for conservation of Western Australian coastal fishes: A comparison of hotspot, biogeographical and complementarity approaches. Biological Conservation 125(4): 399-410.

Gaston, K.J. and Mound, L.A. (1993). Taxonomy, hypothesis testing and the biodiversity crisis. Proceedings: Biological Sciences 251(1331): 139-142.

Gislén, T. (1919). Results of Dr. E. Mjöberg's Swedish scientific expeditions to Australia 1910-1913. Part XXIII. Crinoids. Kunglia Svenska Vetenskapsakademiens handlingar 59(4): 1-37.

Graham, C.H., Ferrier, S., Huettman, F., Moritz, C. and Peterson, A.T. (2004). New developments in museumbased informatics and applications in biodiversity analysis. Trends in Ecology and Evolution 19(9): 497-503.

Gray, J.S. (1997). Marine biodiversity: patterns, threats and conservation needs. Biodiversity and Conservation 6(1): 153-175.

Harnik, P.G. (2009). Unveiling rare diversity by integrating museum, literature, and field data. Paleobiology 35(2): 190. 
Hoeksema, B.W. (2007). Chapter 5. Delineation of the Indo-Malayan centre of maximum marine biodiversity: the coral triangle (pp. 117-178). In: Renema, W. (ed.), Biogeography, time, and place: distributions, barriers, and islands. Topics in Geobiology, volume 29. Springer: Dordercht, The Netherlands.

Hoeksema, B.W., van der Land, J., van der Meij, S.E.T., van Ofwegen, L.P., Reijnen, B.T., van Soest, R.W.M. and de Voogd, N.J. (2011). Unforeseen importance of historical collections as baselines to determine biotic change of coral reefs: the Saba Bank case. Marine Ecology 32(2): 135-141.

Hoggett, A.K. (1990). Taxonomy and systematic position of the brittlestar genus Macrophiothrix H.L. Clark (Echinodermata: Ophiuroidea). PhD thesis, University of Queensland: Brisbane.

Hoggett, A.K. (1991). The genus Macrophiothrix (Ophiuroidea: Ophiotrichidae) in Australian waters. Invertebrate Systematics 4(5): 1077-1146.

Hoggett, A.K. (2006). A new species of Macrophiothrix (Ophiuroidea: Ophiotrichidae) common in northern Australia. Zootaxa 1326: 17-24.

Hooper, J.N.A. and Ekins, M. (eds) (2004). Collation and validation of museum collection databases related to the distribution of marine sponges in northern Australia. Unpublished Report. Commonwealth of Australia and Queensland Museum: Canberra.

Huisman, J.M., Jones, D.S., Wells, F.E. and Burton, T. (2008). Introduced marine biota in Western Australian waters. Records Western Australian Museum 25: 1-44.

Huisman, J.M., Leliaert, F., Verbruggen, H. and Townsend, R.A. (2009). Marine benthic plants of Western Australia's shelf-edge atolls. Records of the Western Australian Museum Supplement 77: 50-88.

Hutchins, J.B. (1999). Biogeography of the nearshore marine fish fauna of the Kimberley, Western Australia. Proceedings of the 5th Indo-Pacific Fish Conference. Society of French Ichthyologists: Nouméa, New Caledonia.

Jones, J.P. and Kaly, U.L. (1995). Criteria for selecting marine organisms in biomonitoring studies. In: Schmitt, R.J. and Osenberg, C.W. (eds), Detecting ecological impacts: concepts and applications in coastal habitats. Academic Press: San Diego, California.

Keesing, J.K., Irvine, T.R., Alderslade, P., Clapin, G., Fromont, J., Hosie, A.M., Huisman, J.M., Naughton, K.M., Marsh, L.M., Slack-Smith, S.M., Thomson, D.P. and Watson, J.E. (2011). Marine benthic flora and fauna of Gourdon Bay and the Dampier Peninsula in the Kimberley region of north-western Australia. Journal of the Royal Society of Western Australia 94(2): 285-301.

King, P.P. (1827). Narrative of a survey of the intertropical and western coasts of Australia. Performed between the years 1818 and 1822. John Murray: London, United Kingdom.

Lamarck, J.B.P.A. de (1816). Stellerides. Histoire naturelle des animaux sans vertèbres Volume 2. Verdière: Paris, France.

Lane, D.J.W., Marsh, L.M., Van den Spiegel, D. and Rowe, F.W.E. (2001). Echinoderm fauna of the South
China Sea: an inventory and analysis of distribution patterns. Raffles Bulletin of Zoology 48: 459-494.

Mah, C. and Foltz, D. (2011). Molecular phylogeny of the Valvatacea (Asteroidea: Echinodermata). Zoological Journal of the Linean Society 161(4): 769-788.

Marchant, L. (1982). France Australe. Artlook Books: Perth, Australia.

Marsh, L.M. (1976). Western Australian Asteroidea since H.L. Clark. Thalassia Jugoslavica 12(1): 213-225.

Marsh, L.M. (1986). Faunal Surveys of the Rowley Shoals, Scott Reef and Seringapatam Reef North-Western Australia. Part IV. Echinoderms. Records of the Western Australian Museum Supplement 25: 63-74.

Marsh, L.M. (1992). Part III. Echinoderms (pp. 23-29). In Survey of the Kimberley Islands and Reefs, Western Australia. Unpublished Report. Western Australian Museum: Perth, Australia.

Marsh, L.M. (2011). The 1990 expedition to Camden Harbour, North-West Kimberley: Part 5 - marine invertebrates. The Western Australian Naturalist 27(4): 268-277.

Marsh, L.M. and Marshall, J.I. (1983). Some aspects of the zoogeography of northwestern Australian echinoderms (other than holothurians). Bulletin of Marine Science 33(3): 671-687.

Marsh, L.M. and Morrison, S.M. (2004). Echinoderms of the Dampier Archipelago, Western Australia. Records of the Western Australian Museum Supplement 66: 293-342.

Marsh, L.M. and Slack-Smith, S.M. (2010). Field guide to sea stingers and other venomous and poisonous marine invertebrates of Western Australia. Western Australian Museum: Perth.

Marsh, L.M., Vail, L.L., Hoggett, A.K. and Rowe, F.W.E. (1993). Echinoderms of Ashmore Reef and Cartier Island (pp. 53-65). In: Berry, PF (ed.), Marine faunal surveys of Ashmore Reef and Cartier Island. Records of the Western Australian Museum, Supplement 44

Massin, C. (1999). Reef-dwelling Holothuroidea (Echinodermata) of the Spermonde Archipelago (South-West Sulawesi, Indonesia). Zoologische Verhandelingen Leiden 329: 3-144.

Mikkelsen, P.M. and Cracraft, J. (2001). Marine biodiversity and the need for systematic inventories. Bulletin of Marine Science 69(2): 525-534.

Mortensen, Th. (1918). Results of Dr. E. Mjöberg's Swedish Scientific Expeditions to Australia 1910-1913. Part XXI. Echinoidea. Kunglia Svenska Vetenskapsakademiens handlingar 58(9): 1-22.

O'Hara, T.D. (2002). Endemism, rarity and vulnerability of marine species along a temperate coastline. Invertebrate Systematics 16(4): 671-684.

O'Hara, T.D. (2007). Seamounts: centres of endemism or species richness for ophiuroids? Global Ecology and Biogeography 16(6): 720-732.

O'Hara, T.D. and Poore, G.C.B. (2000). Patterns of distribution for southern Australian marine echinoderms and decapods. Journal of Biogeography 27(6): 1321-1335.

O'Hara, T.D., Rowden A.A., and Bax N.J. (2011). A southern hemisphere bathyal fauna is distributed in latitudinal bands. Current Biology 21: 226-230. 
O'Loughlin, P.M. (1991). Brooding and fission in shallow water echinoderms of southern Australia. In: Yanagisawa, T., Yasumasu, I., Oguro, C., Suzuki, N., Motokawa, T. (eds), Biology of Echinodermata. A.A. Balkema: Rotterdam, The Netherlands.

O'Loughlin, P.M. and Rowe, F.W.E. (2006). A systematic revision of the asterinid genus Aquilonastra O'Loughlin, 2004 (Echinodermata: Asteroidea). Memoirs of Museum Victoria 63(2): 257-287.

O'Loughlin, P.M. and Waters, J.M. (2004). A molecular and morphological revision of genera of Asterinidae (Echinodermata: Asteroidea). Memoirs of Museum Victoria 61(1): 1-40.

Padial, J.M., Miralles, A., De la Riva, I. and Vences, M. (2010). The integrative future of taxonomy. Frontiers in Zoology 7: 1-14.

Pyke, G.H. and Ehrlich, P.R. (2010). Biological collections and ecological/environmental research: a review, some observations and a look to the future. Biological Reviews 85(2): 247-266.

Rankin, L.R. and Messing, C.G. (2008). A revision of the comatulid genus Stephanometra AH Clark with a rediagnosis of the genus Lamprometra AH Clark (Echinodermata: Crinoidea). Zootaxa 1888: 1-35.

Rowe, F.W.E. and Gates, J. (1995). Echinodermata. In: Wells, A. (ed.), Zoological Catalogue of Australia. Volume 33. CSIRO: Melbourne.

Sampey, A., Bryce, C., Osborne, S. and Miles, A. (2014). Kimberley marine biota: Historical data: introduction and methods. Records of the Western Australian Museum Supplement 84: 19-43.

Semeniuk, V. (1993). The mangrove systems of Western Australia: 1993 presidential address. Journal of the Royal Society of Western Australia 76(4): 99-122.
Stickle, W.B. and Diehl, W.J. (1987). Effects of salinity on echinoderms. Echinoderm studies 2: 235-285.

Uthicke, S., Schaffelke, B. and Byrne, M. (2009). A boom-bust phylum? Ecological and evolutionary consequences of density variations in echinoderms. Ecological Monographs 79(1): 3-24.

Vogler, C., Benzie, J., Lessios, H., Barber, P. and Wörheide, G. (2008). A threat to coral reefs multiplied? Four species of crown-of-thorns starfish. Biology Letters 4(6): 696.

Webb, T.J., Tyler, E.H.M. and Somerfield, P.J. (2009). Life history mediates large-scale population ecology in marine benthic taxa. Marine Ecology Progress Series 396: 293-306.

Wilson, B. (2013). The Biogeography of the Australian North West Shelf: Environmental Change and Life's Response. Elsevier: Burlington, MA, United States of America.

Wilson, B.R. (2014). Kimberley Marine biota: historical and environmental introduction. Records of the Western Australian Museum Supplement 84: 1-18.

Wood, M. and Mills, D. (eds) (2008). A turning of the tide: science for decisions in the Kimberley-Browse marine region. Unpublished Report. Western Australian Marine Science Institute: Perth.

Yamaguchi, M. and Lucas, J.S. (1984). Natural parthenogenesis, larval and juvenile development, and geographical distribution of the coral reef asteroid Ophidiaster granifer. Marine Biology 83(1): 33-42.

Zar, J.H. (1999). Biostatistical Analysis. $4^{\text {th }}$ Edition. Prentice Hall International, Inc.: Upper Saddle River, New Jersey, United States of America.

MANUSCRIPT RECEIVED 15 JUNE 2014; ACCEPTED 20 JANUARY 2015. 
APPENDIX 1 Number of registered specimen lots of echinoderm families from the Project Area housed in Australian museum collections. Included are those lots identified to species or able to be distinguished as a species entity, and excluded are those lots incompletely identified (out of parentheses) or from deepwater (>30 m) locations (in parentheses).

\begin{tabular}{|c|c|c|c|c|c|}
\hline Included Specimens & AM & MAGNT & WAM & MV & Total \\
\hline \multicolumn{6}{|l|}{ Class: Asteroidea } \\
\hline Acanthasteridae & & 1 & 2 & & 3 \\
\hline Archasteridae & 2 & 1 & 2 & & 5 \\
\hline Asterinidae & 13 & 5 & 38 & & 56 \\
\hline Asteropseidae & & & 9 & & 9 \\
\hline Astropectinidae & 13 & 3 & 26 & & 42 \\
\hline Echinasteridae & 4 & 7 & 17 & 4 & 32 \\
\hline Goniasteridae & 12 & & 10 & & 22 \\
\hline Luidiidae & 2 & 1 & & & 3 \\
\hline Mithrodiidae & & & 2 & & 2 \\
\hline Ophidiasteridae & 4 & 46 & 128 & 8 & 186 \\
\hline Oreasteridae & 30 & 6 & 84 & 1 & 121 \\
\hline Pterasteridae & 1 & & 2 & & 3 \\
\hline Class: Crinoidea & & & & & 0 \\
\hline Antedonidae & 1 & 6 & 9 & & 16 \\
\hline Colobometridae & 2 & 9 & 16 & & 27 \\
\hline Comasteridae & 36 & 64 & 120 & & 220 \\
\hline Himerometridae & 3 & & 4 & & 7 \\
\hline Mariametridae & 3 & 17 & 33 & & 53 \\
\hline Zygometridae & 10 & 1 & 8 & & 19 \\
\hline Class: Echinoidea & & & & & 0 \\
\hline Arachnoididae & 7 & & 21 & & 28 \\
\hline Astriclypeidae & 2 & & 1 & & 3 \\
\hline Brissidae & 1 & 3 & 24 & 2 & 30 \\
\hline Cidaridae & 6 & 3 & 33 & 3 & 45 \\
\hline Clypeasteridae & 1 & 1 & 6 & & 8 \\
\hline Diadematidae & & 13 & 22 & 2 & 37 \\
\hline Echinolampadidae & 1 & 6 & 15 & 3 & 25 \\
\hline Echinometridae & & 1 & 13 & 2 & 16 \\
\hline Echinoneidae & & 1 & 8 & & 9 \\
\hline Fibulariidae & 2 & & 5 & & 7 \\
\hline Laganidae & 15 & 2 & 33 & & 50 \\
\hline Loveniidae & 6 & 5 & 22 & 2 & 35 \\
\hline Parasaleniidae & 1 & 1 & 20 & & 22 \\
\hline Schizasteridae & 2 & & 1 & & 3 \\
\hline Spatangidae & & & 1 & & 1 \\
\hline Temnopleuridae & 8 & 3 & 36 & 1 & 48 \\
\hline Toxopneustidae & 3 & 5 & 11 & & 19 \\
\hline Class: Holothuroidea & & & & & 0 \\
\hline Caudinidae & 1 & & & & 1 \\
\hline Chiridotidae & & 3 & 2 & & 5 \\
\hline Cucumariidae & 25 & 10 & 17 & & 52 \\
\hline
\end{tabular}

\begin{tabular}{llllll} 
Included Specimens & AM & MAGNT & WAM & MV & Total \\
\hline Holothuriidae & 12 & 120 & 185 & 6 & $\mathbf{3 2 3}$ \\
Phyllophoridae & 20 & 7 & 18 & & $\mathbf{4 5}$ \\
Sclerodactylidae & 5 & 7 & 8 & 1 & $\mathbf{2 1}$ \\
Stichopodidae & 4 & 28 & 26 & 1 & $\mathbf{5 9}$ \\
Synaptidae & 11 & 10 & 21 & 2 & $\mathbf{4 4}$ \\
Class: Ophiuroidea & & & & & $\mathbf{0}$ \\
Amphiuridae & 19 & 4 & 34 & 5 & $\mathbf{6 2}$ \\
Euryalidae & 2 & 1 & 1 & 1 & $\mathbf{5}$ \\
Gorgonocephalidae & & & 1 & & $\mathbf{1}$ \\
Ophiactidae & 8 & 8 & 51 & 2 & $\mathbf{6 9}$ \\
Ophiocomidae & 2 & 49 & 169 & 20 & $\mathbf{2 4 0}$ \\
Ophiodermatidae & 16 & 16 & 92 & 11 & $\mathbf{1 3 5}$ \\
Ophiolepididae & 10 & 15 & 28 & 3 & $\mathbf{5 6}$ \\
Ophiomyxidae & & & 6 & & $\mathbf{6}$ \\
Ophionereididae & 7 & 4 & 27 & 4 & $\mathbf{4 2}$ \\
Ophiotrichidae & 33 & 129 & 195 & 12 & $\mathbf{3 6 9}$ \\
Ophiuridae & 8 & 1 & 5 & & $\mathbf{1 4}$ \\
\hline Total & $\mathbf{3 7 4}$ & $\mathbf{6 2 3}$ & $\mathbf{1 , 6 6 8}$ & $\mathbf{9 6}$ & $\mathbf{2 , 7 6 1}$ \\
\hline
\end{tabular}




\begin{tabular}{|c|c|c|c|c|c|c|c|c|c|c|c|}
\hline Excluded Specimens & AM & MAGNT & WAM & MV & Total & Excluded Specimens & AM & MAGNT & WAM & MV & Total \\
\hline Class: Asteroidea & & & $1(139)$ & & 140 & Loveniidae & 1 & & $9(11)$ & & 21 \\
\hline Acanthasteridae & & & 1 & & 1 & Micropygidae & 4 & & & & 4 \\
\hline Asteriidae & $(2)$ & & $(2)$ & & 4 & Neolampidae & $(2)$ & & & & 2 \\
\hline Asterinidae & 2 & $2(1)$ & $10(5)$ & & 20 & Pedinidae & & $(1)$ & (1) & & 2 \\
\hline Asterodiscididae & & & $1(1)$ & & 2 & Pericosmidae & (1) & (3) & $(8)$ & 1 & 13 \\
\hline Asteropseidae & & & 2 & & 2 & Phormosomatidae & (3) & & & & 3 \\
\hline Astropectinidae & & (3) & $3(46)$ & & 52 & Psychocidaridae & (1) & & & & 1 \\
\hline Benthopectinidae & $(1)$ & & $(22)$ & & 23 & Saleniidae & & & $(1)$ & & 1 \\
\hline Brisingasteridae & & & (1) & & 1 & Temnopleuridae & 9 & $(1)$ & $3(3)$ & & 16 \\
\hline Brisingidae & & & (5) & & 5 & Toxopneustidae & 1 & & 3 & & 4 \\
\hline Echinasteridae & 1 & $1(1)$ & $13(7)$ & & 23 & Class: Holothuroidea & & & $45(49)$ & & 94 \\
\hline Goniasteridae & 7 & $(15)$ & $1(259)$ & & 282 & Caudinidae & 1 & & & & 1 \\
\hline Goniopectinidae & & $(1)$ & $(46)$ & & 47 & Cucumariidae & 1 & $(11)$ & $2(9)$ & & 23 \\
\hline Luidiidae & 2 & 1 & $2(3)$ & & 8 & Holothuriidae & 3 & 7 & $40(32)$ & & 82 \\
\hline Mithrodiidae & 1 & & 1 & & 2 & Phyllophoridae & & (3) & $5(1)$ & & 9 \\
\hline Ophidiasteridae & 9 & $1(1)$ & $39(15)$ & & 65 & Sclerodactylidae & & & $(1)$ & & 1 \\
\hline Oreasteridae & 8 & $2(6)$ & $9(15)$ & & 40 & Stichopodidae & & 1 & 8 & & 9 \\
\hline Pterasteridae & & & $(4)$ & & 4 & Synallactidae & & $(2)$ & & & 2 \\
\hline Solasteridae & & & (1) & & 1 & Synaptidae & 1 & & 5 & & 6 \\
\hline Zoroasteridae & & (5) & (7) & & 12 & Ypsilothuriidae & & & (9) & & 9 \\
\hline Class: Crinoidea & & & $(50)$ & & 50 & Class: Ophiuroidea & & 2 & $2(93)$ & & 97 \\
\hline Antedonidae & & & $1(1)$ & & 2 & Amphiuridae & & 1 & $8(12)$ & & 21 \\
\hline Asterometridae & & & $(1)$ & & 1 & Asteroschematidae & 3 & & (5) & & 8 \\
\hline Calometridae & 3 & & (1) & & 4 & Euryalidae & 1 & $(2)$ & $(16)$ & & 19 \\
\hline Colobometridae & 1 & 4 & $3(1)$ & & 9 & Gorgonocephalidae & (3) & $(2)$ & $(26)$ & & 31 \\
\hline Comasteridae & 12 & $32(3)$ & $13(12)$ & & 72 & Hemieuryalidae & & & $(2)$ & & 2 \\
\hline Himerometridae & 6 & 1 & $(2)$ & & 9 & Ophiacanthidae & 1 & & $1(130)$ & & 132 \\
\hline Isocrinidae & $(1)$ & (3) & $(15)$ & & 19 & Ophiactidae & & $(1)$ & $6(8)$ & & 15 \\
\hline Mariametridae & & & 9 & & 9 & Ophiocomidae & & $(1)$ & 47 & & 48 \\
\hline Thalassometridae & & (3) & (3) & & 6 & Ophiodermatidae & 4 & $(2)$ & $14(12)$ & & 32 \\
\hline Zygometridae & 7 & $(1)$ & $(1)$ & & 9 & Ophioleucidae & & & $(1)$ & & 1 \\
\hline Class: Echinoidea & 3 & & $9(126)$ & & 138 & Ophiomyxidae & 1 & & 2 & & 3 \\
\hline Apatopygidae & 1 & & & & 1 & Ophionereididae & & & $3(2)$ & & 5 \\
\hline Arachnoididae & & & 1 & & 1 & Ophiotrichidae & 5 & $1(4)$ & $77(42)$ & & 129 \\
\hline Arbaciidae & $(2)$ & & $(4)$ & & 6 & Ophiuridae & & & $2(38)$ & & 40 \\
\hline Asterostomatidae & & & (1) & & 1 & Unidentified & & & & & \\
\hline Brissidae & 1 & 1 & $19(5)$ & & 26 & echinoderms & & & $1(3)$ & & 4 \\
\hline Cassidulidae & (1) & & & & 1 & Total & 155 & 140 & 1847 & 4 & 2146 \\
\hline Cidaridae & 17 & $(4)$ & $3(29)$ & & 53 & & & & & & \\
\hline Clypeasteridae & 1 & $(1)$ & $2(3)$ & & 7 & & & & & & \\
\hline Diadematidae & 3 & $(2)$ & 9 & & 14 & & & & & & \\
\hline Echinolampadidae & & & $2(1)$ & & 3 & & & & & & \\
\hline Echinometridae & & & $11(10)$ & 3 & 24 & & & & & & \\
\hline Echinoneidae & & & 8 & & 8 & & & & & & \\
\hline Echinothuriidae & 8 & & & & 8 & & & & & & \\
\hline Fibulariidae & 7 & & $2(14)$ & & 23 & & & & & & \\
\hline Holasteridae & (1) & & (1) & & 2 & & & & & & \\
\hline Laganidae & 2 & & $8(7)$ & & 17 & & & & & & \\
\hline
\end{tabular}


APPENDIX 2 Species of echinoderms recorded from the Project Area. Codes are defined in the methods. Superscripts associated with the species name indicate type material, Holotype ${ }^{H}$, Paratype ${ }^{P}$; NB. The following paratypes, Actinocucumis longipedes*, Amphiura phrixa**, Archaster laevis** were synonymised with the listed species. Species listed in Keesing et al. (2011), but not in our Kimberley Project Area database ${ }^{k}$. Superscripts associated with the EZ habitat code indicates the animal associated with echinoderm species (sponges ${ }^{1}$, corals ${ }^{2}$, gorgonians ${ }^{3}$, soft corals ${ }^{4}$, sessile invertebrates ${ }^{5}$ and crinoids $^{6}$ ).

\begin{tabular}{llll} 
& Habitat & Biogeographic & \\
Taxa & Code & Region & Inshore Offshore \\
\hline
\end{tabular}

\section{Class: Asteroidea}

Family: Acanthasteridae

Acanthaster planci (Linnaeus, 1758)

$\begin{array}{ll}\mathrm{H}^{\mathrm{s}} & \text { IP } \\ \mathrm{S}^{\mathrm{s}} & \text { IA } / \mathrm{IO} \\ \mathrm{H}^{\mathrm{s}} & \text { WP } \\ & \\ \mathrm{S}^{\mathrm{s}} & \text { IA } \\ \mathrm{H} / \mathrm{S}^{\text {is }} & \text { IWP } \\ \mathrm{H} / \mathrm{S}^{\text {is }} & \text { IA } \\ \mathrm{H} / \mathrm{S}^{\text {is }} & \text { IA } \\ \mathrm{H}^{\mathrm{i}} & \text { IWP } \\ \mathrm{H}^{\text {is }} & \text { IA } \\ {\mathrm{H} / \mathrm{S}^{\text {is }}}^{\text {is }} & \text { IA } \\ \mathrm{S}^{\text {is }} & \text { IA }\end{array}$

Family: Archasteridae

Archaster angulatus Muller \& Troschel, $1842^{\mathrm{P} * * *}$

Archaster typicus Müller \& Troschel, 1840

\section{Family: Asterinidae}

Anseropoda rosacea (Lamarck, 1816)

Aquilonastra anomala (H.L. Clark, 1921)

Aquilonastra cepheus (Müller \& Troschel, 1842)

Aquilonastra coronata (von Martens, 1866)

Disasterina abnormalis Perrier, 1875

Indianastra sarasini (de Loriol, 1897)

Nepanthia belcheri (Perrier, 1875)

Nepanthia maculata Gray, 1840

\section{Family: Asteropseidae}

Asteropsis carinifera (Lamarck, 1816)

Valvaster striatus (Lamarck, 1816)

$\begin{array}{ll}\mathrm{H}^{\text {is }} & \text { IWP } \\ \mathrm{H}^{\text {is }} / \mathrm{S}^{\mathrm{s}} & \text { IWP }\end{array}$

\section{Family: Astropectinidae}

Astropecten granulatus Müller \& Troschel, 1842

Astropecten monacanthus Sladen, 1883

Astropecten vappa Müller \& Troschel, 1843

Astropecten velitaris von Martens, 1865

Astropecten zebra Sladen, 1883

\section{Family: Echinasteridae}

Echinaster callosus Marenzeller, 1895

Echinaster luzonicus (Gray, 1840)

Echinaster superbus H.L. Clark, 1916

Echinaster varicolor H.L. Clark, 1938 ${ }^{\mathrm{P}}$

Metrodira subulata Gray, 1840

\section{Family: Goniasteridae}

Anthenoides dubius H.L. Clark, 1938 ${ }^{\mathrm{P}}$

Celerina heffernani (Livingstone, 1931)

Fromia eusticha Fisher, 1913

Fromia indica (Perrier, 1869)

Fromia milleporella (Lamarck, 1816)

Fromia monilis Perrier, 1869

Iconaster longimanus (Möbius, 1859)

Ss

Ss

$S^{s}$

$S^{s}$

$\mathrm{IA} / \mathrm{IO}$

IWP

$\mathrm{IA} / \mathrm{IO}$

$\mathrm{IA} / \mathrm{IO}$

$\mathrm{IA} / \mathrm{IO}$

$\begin{array}{ll}\mathrm{H}^{\text {s }} & \text { IWP } \\ \mathrm{H}^{\text {is }} & \text { IWP } \\ \mathrm{S}^{\text {is }} & \text { WA } \\ {\mathrm{H} / \mathrm{S}^{\mathrm{s}} / \mathrm{SG}}^{\mathrm{S}} & \text { IA } \\ \mathrm{S}^{\mathrm{s}} & \text { IA } / \mathrm{IO}\end{array}$

$\mathrm{S}^{\mathrm{s}}$

$\mathrm{H}^{\mathrm{s}}$

WA

$\mathrm{H}^{\mathrm{s}}$

IWP

$\mathrm{H}^{\mathrm{is}} \quad$ IWP

$\mathrm{H}^{\mathrm{is}} \quad$ IWP

$\mathrm{H}^{\mathrm{is}} \quad$ IWP

$\mathrm{H} / \mathrm{S}^{s} \quad$ IWP 


\begin{tabular}{llll} 
& \multicolumn{1}{c}{ Habitat } & Biogeographic \\
Region & Code & Inshore & Offshore \\
\hline Neoferdina cumingi (Gray, 1840) & $\mathrm{H}^{\mathrm{s}}$ & $\mathrm{IWP}$ & $\bullet$ \\
Stellaster childreni Gray, 1840 & $\mathrm{S}^{\mathrm{s}}$ & $\mathrm{IA} / \mathrm{IO}$ & $\bullet$ \\
Stellaster princeps Sladen, 1889 & $\mathrm{~S}^{\mathrm{s}}$ & $\mathrm{NA}$ & $\bullet$ \\
Family: Luidiidae & & & $\bullet$ \\
Luidia hardwicki (Gray, 1840) & $\mathrm{S}^{\mathrm{s}}$ & $\mathrm{IA} / \mathrm{IO}$ & $\bullet$ \\
Luidia maculata Muller \& Troschel, 1842 & $\mathrm{~S}^{\mathrm{s}}$ & $\mathrm{IWP}$ & $\bullet$
\end{tabular}

\section{Family: Mithrodiidae}

Mithrodia clavigera (Lamarck, 1816)

$\mathrm{H}^{\mathrm{is}}$

IWP

Family: Ophidiasteridae

Bunaster ritteri Döderlein, 1896

Cistina columbiae Gray, 1840

Dactylosaster cylindricus (Lamarck, 1816)

Gomophia gomophia (Perrier, 1875)

Gomophia sphenisci (A.M. Clark, 1967)

Hacelia helicosticha (Sladen, 1889)

Leiaster speciosus von Martens, 1866

Linckia guildingi Gray, 1840

Linckia laevigata (Linnaeus, 1758)

Linckia multifora (Lamarck, 1816)

Nardoa tuberculata Gray, 1840

Ophidiaster cribrarius Lütken, 1871

Ophidiaster granifer Lütken, 1871

Ophidiaster hemprichi Müller \& Troschel, 1842

Tamaria megaloplax (Bell, 1884)

Tamaria tumescens (Koehler, 1910)

\section{Family: Oreasteridae}

Anthenea australiae Doderlein, 1915

Anthenea conjungens Döderlein, 1935

Anthenea elegans H.L. Clark, 1938

Anthenea godeffroyi Döderlein, 1915

Anthenea polygnatha H.L. Clark, 1938

Choriaster granulatus Lütken, 1869

Culcita novaeguineae Müller \& Troschel, 1842

Culcita schmideliana (Retzius, 1805)

Goniodiscaster acanthodes H.L. Clark, 1938P

Goniodiscaster australiae Tortonese, 1937

Goniodiscaster rugosus (Perrier, 1875)

Gymnanthenea globigera (Döderlein, 1915)

Pentaceraster multispinus (von Martens, 1866)

Pentaceraster regulus (Müller \& Troschel, 1842)

Protoreaster lincki (Blainville, 1830)

Protoreaster nodosus (Linnaeus, 1758)

Protoreaster nodulosus (Perrier, 1875)

Pseudoreaster obtusangulus (Lamarck, 1816)

\section{Family: Pterasteridae}

Euretaster insignis (Sladen, 1882)

$\begin{array}{ll}\mathrm{H}^{\text {is }} & \text { IA } \\ \mathrm{H}^{\mathrm{s}} & \text { IWP } \\ \mathrm{H}^{\mathrm{i}} & \text { IP } \\ \mathrm{H}^{\mathrm{s}} & \text { IWP } \\ \mathrm{S}^{\mathrm{s}} & \text { NA } \\ \mathrm{H} / \mathrm{S}^{\mathrm{s}} & \text { WP } \\ \mathrm{H}^{\mathrm{s}} & \text { IWP } \\ \mathrm{H}^{\text {is }} & \text { T } \\ \mathrm{H}^{\text {is }} & \text { IWP } \\ \mathrm{H}^{\text {is }} & \text { IWP } \\ \mathrm{H}^{\text {is }} & \text { IWP } \\ \mathrm{H}^{\text {is }} & \text { IWP } \\ \mathrm{H}^{\text {is }} & \text { IWP } \\ \mathrm{H}^{\text {is }} & \text { IWP } \\ \mathrm{H}^{\text {is }} & \text { IA } \\ \mathrm{S}^{\mathrm{s}} & \text { IA }\end{array}$

IA

WP

IWP

NA

WP

WP

IWP

IWP

WP

IWP

IWP

IA

$\mathrm{H} / \mathrm{S}^{\mathrm{s}}$

WA

$\mathrm{H} / \mathrm{S}^{\mathrm{s}}$

NA

$\mathrm{H} / \mathrm{S}^{\mathrm{s}}$

$S^{s}$

Ss

NA

NA

$\mathrm{H}^{\text {is }}$

WA

IWP

$\mathrm{H}^{\text {is }} / \mathrm{S}^{\mathrm{s}}$

$\mathrm{H} / \mathrm{S}^{\mathrm{s}}$

$\mathrm{S}^{\mathrm{s}}$

$S^{s}$

$\mathrm{H}^{\text {is }} / \mathrm{S}^{\mathrm{s}}$

$\mathrm{S}^{\mathrm{i}}$

$\mathrm{H} / \mathrm{S}$ is $/ \mathrm{SG} \quad$ IWP

$\mathrm{H} / \mathrm{S}^{\text {is }} / \mathrm{SG} \quad \mathrm{IO}$

$\mathrm{H} / \mathrm{S}^{\text {is }} / \mathrm{SG}$ IWP

$\mathrm{H} / \mathrm{S}^{\text {is }}$

Ss

WA

WA

$S^{s}$

IWP 


\begin{tabular}{lllll} 
& Habitat & Biogeographic & Inshore & Offshore \\
\hline
\end{tabular}

Class: Crinoidea

Family: Antedonidae

Dorometra nana (Hartlaub, 1890)

Dorometra parvicirra (Carpenter, 1888)

Euantedon cf. polytes A.H. Clark, 1936

Toxometra nomina (H.L. Clark, 1938) ${ }^{\mathrm{P}}$

Family: Colobometridae

Basilometra boschmai A.H. Clark, 1936

Cenometra bella (Hartlaub, 1890)

Cenometra cf. emendatrix (Bell, 1892)

Cenometra cf. herdmani A.H. Clark, 1909

Colobometra perspinosa (Carpenter, 1881)

Decametra laevipinna (A.H. Clark, 1912)

Decametra parva (A.H. Clark, 1912)

Iconometra anisa (H.L. Clark, 1915)

Oligometra serripinna (Carpenter, 1881)

Oligometrides adeonae (Lamarck, 1816)

Petasometra clarae (Hartlaub, 1890)

Petasometra helianthoides A.H. Clark, 1912

Pontiometra andersoni (Carpenter, 1889)

\section{Family: Comasteridae}

Capillaster multiradiata (Linnaeus, 1758)

Capillaster sentosa (Carpenter, 1888)

Clarkcomanthus littoralis (Carpenter, 1888)

Clarkcomanthus luteofuscum (H.L. Clark, 1915)

Comanthina variabilis (Bell, 1882)

Comanthus alternans (Carpenter, 1881)

Comanthus briareus (Bell, 1882)

Comanthus gisleni Rowe et al., 1986

Comanthus mirabilis Rowe, et al., 1986

Comanthus parvicirrus (Müller, 1841)

Comanthus suavia Rowe, Hoggett, Birtles \& Vail, 1986

Comanthus wahlbergii (Müller, 1843)

Comaster audax? (Rowe, Hoggett, Birtles \& Vail, 1986)

Comaster multifidus (Müller, 1841)

Comaster schlegelii (Carpenter, 1881)

Comatella maculata (Carpenter, 1888)

Comatella stelligera (Carpenter, 1888)

Comatula pectinata (Linnaeus, 1758)

Comatula purpurea (Müller, 1843)

Comatula rotalaria Lamarck, 1816

Comatula solaris Lamarck, 1816

Oxycomanthus bennetti (Müller, 1841)

Oxycomanthus comanthipinna (Gislén, 1922)

Oxycomanthus exilis Rowe et al., 1986
$\mathrm{H}^{\mathrm{s}}$

$\mathrm{H}^{\mathrm{s}}$

$\mathrm{H}^{\mathrm{s}}$

$\mathrm{H}^{\mathrm{s}}$

IA

IA

WP

WA

$\begin{array}{ll}\mathrm{H}^{\mathrm{s}} & \text { IA } \\ \mathrm{H}^{\mathrm{s}} / \mathrm{EZ}^{3} & \text { IWP } \\ \mathrm{H}^{\mathrm{s}} & \text { IO } \\ \mathrm{H}^{\mathrm{s}} & \text { IA } \\ \mathrm{H}^{\mathrm{s}} / \mathrm{EZ}^{3} & \text { WP } \\ \mathrm{H}^{\mathrm{s}} / \mathrm{EZ}^{3} & \text { IA } \\ \mathrm{H}^{\mathrm{s}} / \mathrm{EZ}^{3} & \text { IA } \\ \mathrm{H}^{\mathrm{s}} & \text { WP } \\ \mathrm{H}^{\mathrm{s}} / \mathrm{EZ}^{3} & \text { IWP } \\ \mathrm{H}^{\mathrm{s}} / \mathrm{EZ}^{3} & \text { IA } \\ \mathrm{H}^{\mathrm{s}} & \text { IA } \\ \mathrm{H}^{\mathrm{s}} & \text { NA } \\ \mathrm{H}^{\mathrm{s}} & \text { IA }\end{array}$

$S^{s}$

$\mathrm{H} / \mathrm{S}^{\mathrm{s}}$

IWP

$\mathrm{H}^{\mathrm{s}}$

$\mathrm{H}^{\text {is }}$

$\mathrm{H} / \mathrm{S}^{\mathrm{s}}$

$\mathrm{H} / \mathrm{S}^{\mathrm{s}}$

$\mathrm{H} / \mathrm{S}^{\mathrm{s}}$

$\mathrm{H}^{\mathrm{s}}$

$\mathrm{H}^{\mathrm{s}} / \mathrm{EZ}^{3} \quad \mathrm{WP}$

$\mathrm{H}^{\mathrm{s}} \quad$ IWP

$\mathrm{H}^{\mathrm{s}} \quad \mathrm{IA}$

$\mathrm{H}^{s} \quad$ IWP

$\mathrm{H}^{\text {is }} \quad \mathrm{IA}$

$\mathrm{H}^{\mathrm{s}} \quad \mathrm{WP}$

$\mathrm{H}^{\mathrm{s}} \quad \mathrm{WP}$

$\mathrm{H}^{\mathrm{s}} \quad$ IWP

$\mathrm{H}^{\mathrm{s}} \quad$ IWP

$\mathrm{H}^{s} \quad$ IWP

$\mathrm{H}^{\mathrm{s}}$ IA

$\mathrm{S}^{\mathrm{I}}$ IA

$\mathrm{H}^{\mathrm{s}}$ IA

$\mathrm{H}^{\mathrm{s}} \quad$ IWP

$\mathrm{H} / \mathrm{S}^{\mathrm{s}} \quad \mathrm{WP}$

$\mathrm{H}^{\mathrm{s}} \quad$ WP 


Taxa

Habitat Biogeographic

Family: Himerometridae

Amphimetra tessellata (Müller, 1841)

Heterometra crenulata (Carpenter, 1882)

Heterometra sarae A.H. Clark, $1941^{\mathrm{K}}$

Himerometra robustipinna (Carpenter, 1881)

Code

Region

Inshore Offshore

Family: Mariametridae

Lamprometra palmata (Müller, 1841)

Stephanometra indica (Smith, 1876)

$\begin{array}{lll}\mathrm{H}^{\mathrm{s}} / \mathrm{EZ}^{3} & \text { WP } & \bullet \\ \mathrm{H}^{\mathrm{s}} & \text { IA } & \bullet \\ \mathrm{H}^{\mathrm{s}} & \text { WP } & \bullet \\ \mathrm{H}^{\mathrm{s}} & \text { IWP }\end{array}$

Family: Zygometridae

Zygometra comata A.H. Clark, 1911

Zygometra elegans (Bell, 1882)

Zygometra microdiscus (Bell, 1882)

Zygometra punctata A.H. Clark, 1912

$\mathrm{H}^{\text {is }} \quad$ IWP

$\mathrm{H}^{\mathrm{is}} \quad$ IWP

Class: Echinoidea

Family: Arachnoididae

Arachnoides placenta (Linnaeus, 1758)

Arachnoides tenuis H.L. Clark, 1938

$S^{\text {is }}$

$\mathrm{S}^{\text {is }}$

IWP

Family: Astriclypeidae

Echinodiscus auritus Leske, 1778

$S^{s}$

IA

$\mathrm{H}^{\mathrm{s}}$
$\mathrm{H}^{\mathrm{s}}$

$\mathrm{H}^{\mathrm{s}}$

IA

IA

IA

Family: Brissidae

Brissus latecarinatus (Leske, 1778)

Brissopsis sp. ${ }^{\mathrm{K}}$

Metalia dicrana H.L. Clark, 1917

Metalia spatagus (Linnaeus, 1758)

Metalia sternalis (Lamarck, 1816)

Rhynobrissus hemiasteroides Agassiz, 1879

Rhynobrissus tumulus McNamara, 1982

\section{Family: Cidaridae}

Eucidaris metularia (Lamarck, 1816)

Phyllacanthus longispinus Mortensen, 1918

Prionocidaris baculosa (Lamarck, 1816)

Prionocidaris bispinosa (Lamarck, 1816)

Prionocidaris verticillata (Lamarck, 1816)

\section{Family: Clypeasteridae}

Clypeaster (Coronanthus) latissimus (Lamarck, 1816) ${ }^{\mathrm{K}}$

Clypeaster (Coronanthus) telurus H.L. Clark, 1914

Clypeaster (Rhaphidoclypus) reticulatus (Linnaeus, 1758)

Clypeaster (Stolonoclypus) virescens Döderlein, $1885^{\mathrm{K}}$

\section{$S^{s}$}

$S^{\text {is }}$

$S^{s}$

Ss

Ss

$S^{s}$

WA

IP

Ss

IWP

IWP

IWP

IWP

WP

$\mathrm{H}^{\text {is }}$

WA

$\mathrm{H}^{\text {is }}$
$\mathrm{H}^{\text {is }}$

IWP

$\mathrm{H}^{\mathrm{is}} \quad \mathrm{NA}$

$\mathrm{H}^{\mathrm{is}}$ IWP

$\mathrm{H} / \mathrm{S}^{\mathrm{s}} \quad \mathrm{IA} / \mathrm{IO}$

$\mathrm{H}^{\text {is }} \mathrm{IA} / \mathrm{IO}$

Family: Diadematidae

Diadema savignyi (Michelin, 1845)

$\mathrm{H}^{\text {is }} / \mathrm{S}^{\mathrm{s}}$

Diadema setosum (Leske, 1778)

$\mathrm{H}^{\text {is }} / \mathrm{S}^{\mathrm{s}}$

$\mathrm{H}^{\text {is }} / \mathrm{S}^{\mathrm{s}}$

IA

Ss IA

$\mathrm{S}^{s} \quad \mathrm{~A}$

$\mathrm{S}^{\mathrm{s}}$

A

$S^{s}$

IP

Echinothrix calamaris (Pallas, 1774)

$\mathrm{H}^{\text {is }} / \mathrm{S}^{\mathrm{s}}$

WP

Echinothrix diadema (Linnaeus, 1758)

Family: Echinolampadidae

Echinolampas ovata (Leske, 1778)

$\mathrm{S}^{\mathrm{s}}$

$\mathrm{IA} / \mathrm{IO}$ 


Taxa

Habitat Biogeographic

Family: Echinometridae

Echinometra mathaei (Blainville, 1825)

Echinostrephus molaris (Blainville, 1825)

Code

Region

Inshore Offshore

Heterocentrotus mammillatus (Linnaeus, 1758)

$\begin{array}{ll}\mathrm{H} / \mathrm{S}^{\mathrm{i}} & \text { IP } \\ \mathrm{H}^{\text {is }} & \text { IW } \\ \mathrm{H} / \mathrm{S}^{\mathrm{i}} & \text { IP } \\ & \\ \mathrm{S}^{\text {is }} & \text { IP } \\ & \\ \mathrm{S}^{\mathrm{s}} & \text { A } \\ \mathrm{S}^{\mathrm{s}} & \text { IA } \\ \mathrm{S}^{\mathrm{s}} & \text { IA } \\ \mathrm{S}^{\mathrm{s}} & \text { IA }\end{array}$

Echinocyamus planissimus H.L. Clark,
Fibularia oblonga Gray, 1851
Fibularia ovulum Lamarck, 1816
Fibularia volva L. Agassiz, 1847
Family: Laganidae
Peronella lesueuri (Valenciennes, 1841)
Peronella orbicularis (Leske, 1778)
Peronella macroproctes Koehler, 1922
Peronella tuberculata Mortensen, 1918

Echinocyamus planissimus H.L. Clark,
Fibularia oblonga Gray, 1851
Fibularia ovulum Lamarck, 1816
Fibularia volva L. Agassiz, 1847
Family: Laganidae
Peronella lesueuri (Valenciennes, 1841)
Peronella orbicularis (Leske, 1778)
Peronella macroproctes Koehler, $1922^{\mathrm{K}}$
Peronella tuberculata Mortensen, 1918

Echinocyamus planissimus H.L. Clark,
Fibularia oblonga Gray, 1851
Fibularia ovulum Lamarck, 1816
Fibularia volva L. Agassiz, 1847
Family: Laganidae
Peronella lesueuri (Valenciennes, 1841)
Peronella orbicularis (Leske, 1778)
Peronella macroproctes Koehler, $1922^{\mathrm{K}}$
Peronella tuberculata Mortensen, 1918

Echinocyamus planissimus H.L. Clark,
Fibularia oblonga Gray, 1851
Fibularia ovulum Lamarck, 1816
Fibularia volva L. Agassiz, 1847
Family: Laganidae
Peronella lesueuri (Valenciennes, 1841)
Peronella orbicularis (Leske, 1778)
Peronella macroproctes Koehler, $1922^{\mathrm{K}}$
Peronella tuberculata Mortensen, 1918

Echinocyamus planissimus H.L. Clark,
Fibularia oblonga Gray, 1851
Fibularia ovulum Lamarck, 1816
Fibularia volva L. Agassiz, 1847
Family: Laganidae
Peronella lesueuri (Valenciennes, 1841)
Peronella orbicularis (Leske, 1778)
Peronella macroproctes Koehler, $1922^{\mathrm{K}}$
Peronella tuberculata Mortensen, 1918

S

S

$S^{\text {is }}$

$\mathrm{S}^{\mathrm{s}}$

$\mathrm{S}^{\text {is }}$

A

IA

IA

IA

Family: Loveniidae

Breynia australasiae (Leach, 1815)

Breynia desorii Gray, 1851

Breynia neanika McNamara, 1982

Lovenia elongata (Gray, 1845) ${ }^{\mathrm{K}}$

$\mathrm{IA} / \mathrm{IO}$

$\mathrm{IA} / \mathrm{IO}$

IA

WA

Family: Parasaleniidae

Parasalenia gratiosa A. Agassiz, 1863

Parasalenia pohlii Pfeffer, 1887

$S^{s}$

Ss

Ss

$S^{s}$

NA

Family: Schizasteridae

Proraster jukesii (Gray, 1851)

Schizaster sp.

$\mathrm{H}^{\text {is }}$

$\mathrm{H}^{\text {is }}$

IWP

Family: Spatangidae

Maretia cordata Mortensen, 1948

IPP

P

Family: Temnopleuridae

Mespilia globulus (Linnaeus, 1758)

Salmacis sphaeroides (Linnaeus, 1758)

Temnopleurus alexandri (Bell, 1884)

Temnopleurus toreumaticus (Leske, 1778)

Temnotrema bothyroides (L. Agassiz, 1846)

Temnotrema elegans Mortensen, 1918

$S^{s}$

Ss

NA

$S^{s}$

Family: Toxopneustidae

Cyrtechinus cf. sp.

cf. Gymnechinus sp. nov. ? ${ }^{\mathrm{K}}$

Nudechinus darnleyensis (Tenison-Woods, 1878)

Nudechinus scotiopremnus H.L. Clark, 1912

Pseudoboletia maculata Troschel, 1869

Toxopneustes pileolus (Lamarck, 1816)

Tripneustes gratilla (Linnaeus, 1758)

$\mathrm{H}^{\text {is }}$

IWP

$\mathrm{S}^{\text {is }}$

IWP

$S^{\text {is }}$

IA

$S^{\text {is }}$

IWP

Ss

IA

S

NA

Ss

$\begin{array}{ll}\mathrm{H}^{\mathrm{i}} / \mathrm{S}^{\text {is }} & \text { NA } \\ \mathrm{H}^{\text {is }} / \mathrm{S}^{\mathrm{s}} & \text { IO } \\ \mathrm{H}^{\mathrm{s}} & \text { IWP } \\ \mathrm{H}^{\mathrm{s}} & \text { IWP } \\ \mathrm{H}^{\text {is }} & \text { IP }\end{array}$




\begin{tabular}{llll} 
& Habitat & Biogeographic & \\
Taxa & Code & Region & Inshore Offshore \\
\hline
\end{tabular}

Class: Holothuroidea

\section{Family: Caudinidae}

Paracaudina chilensis (Muller, 1850)

\section{Family: Chiridotidae}

Chiridota rigida Semper, 1868

Chiridota stuhlmanni Lampert, 1896

Trochodota maculata H.L. Clark, 1921

\section{Family: Cucumariidae}

Actinocucumis typica Ludwig, $1875^{\mathrm{p} *}$

Cercodemas anceps (Selenka, 1867)

Colochirus crassus Ekman, 1918

Colochirus quadrangularis Troschel, 1846

Colochirus robustus Östergren, 1898

Leptopentacta grisea H.L. Clark, 1928

Mensamaria intercedens (Lampert, 1885)

cf. Neocucumis sp.

Plesiocolochirus australis (Ludwig, 1875)

Plesiocolochirus dispar (Lampert, 1889)

Pseudocolochirus violaceus (Theel, 1886)

Staurothyone cf. rosacea (Semper, 1869)

$\begin{array}{ll}\mathrm{S}^{s} & \text { IP } \\ & \\ \mathrm{H} / \mathrm{S}^{\mathrm{s}} & \text { IWP } \\ \mathrm{S}^{\text {is }} & \text { IWP } \\ \mathrm{S}^{\mathrm{s}} & \text { NA }\end{array}$

\section{Family: Holothuriidae}

Actinopyga echinites (Jaeger, 1833)

Actinopyga lecanora (Jaeger, 1833)

Actinopyga mauritiana (Quoy \& Gaimard, 1833)

Actinopyga miliaris (Quoy and Gaimard, 1833)

Actinopyga obesa (Selenka, 1867)

Actinopyga serratidens Pearson, 1903

Bohadschia argus (Jaeger, 1833)

Bohadschia marmorata (Jaeger, 1833)

Holothuria albiventer Semper, 1868

Holothuria arenicola Semper, 1868

Holothuria atra Jaeger, 1833

Holothuria coluber Semper, 1868

Holothuria conica? H.L. Clark, 1938

Holothuria difficilis Semper, 1868

Holothuria edulis Lesson, 1830

Holothuria fuscocinerea Jaeger, 1833

Holothuria fuscogilva Cherbonnier, 1980

Holothuria fuscopunctata Jaeger, 1833

Holothuria fuscorubra Théel, 1886

Holothuria hilla Lesson, 1830

Holothuria impatiens (Forskål, 1775)

Holothuria inhabilis Selenka, 1867

Holothuria lessoni Massin, Uthicke, Purcell, Rowe, Samyn, 2009

Holothuria leucospilota (Brandt, 1835)

Holothuria lineata Ludwig, 1875

$\begin{array}{lll}\mathrm{U} & \mathrm{IWP} & \bullet \\ \mathrm{H}^{\mathrm{s}} & \mathrm{WP} & \bullet \\ \mathrm{H}^{\mathrm{s}} & \mathrm{IA} & \bullet \\ \mathrm{H}^{\mathrm{s}} & \mathrm{WP} & \bullet \\ \mathrm{H}^{\mathrm{s}} & \mathrm{IA} & \bullet \\ \mathrm{S}^{\mathrm{s}} & \mathrm{NA} & \bullet \\ \mathrm{S}^{\mathrm{s}} & \mathrm{IA} & \bullet \\ \mathrm{U} & & \bullet \\ \mathrm{H}^{\mathrm{s}} & \mathrm{WP} & \bullet \\ \mathrm{H}^{\mathrm{s}} & \mathrm{IA} / \mathrm{IO} & \bullet \\ \mathrm{H}^{\mathrm{s}} & \mathrm{IWP} & \bullet \\ \mathrm{H}^{\mathrm{s}} & \mathrm{IO} & \bullet\end{array}$

\begin{tabular}{|c|c|c|}
\hline $\mathrm{H}^{\mathrm{i}} / \mathrm{S}^{\text {is }}$ & IWP & \\
\hline $\mathrm{H}^{\text {is }}$ & IWP & $\bullet$ \\
\hline $\mathrm{H}^{\mathrm{is}}$ & IWP & $\bullet$ \\
\hline $\mathrm{H}^{\mathrm{s}} / \mathrm{S}^{\text {is }}$ & IWP & \\
\hline$S^{s}$ & WP & \\
\hline $\mathrm{U}$ & IWP & \\
\hline $\mathrm{H}^{\mathrm{i}} / \mathrm{S}^{\mathrm{is}}$ & IWP & \\
\hline $\mathrm{S}^{\text {is }}$ & IWP & $\bullet$ \\
\hline $\mathrm{S}^{\mathrm{s}}$ & IWP & $\bullet$ \\
\hline $\mathrm{H} / \mathrm{S}^{\mathrm{s}}$ & $\mathrm{T}$ & $\bullet$ \\
\hline $\mathrm{H}^{\text {is }} / \mathrm{S}^{\mathrm{s}}$ & IP & $\bullet$ \\
\hline $\mathrm{S}^{\text {is }}$ & IA & \\
\hline $\mathrm{S}^{\text {is }}$ & NA & $\bullet$ \\
\hline$S^{s}$ & IP & $\bullet$ \\
\hline $\mathrm{H}^{\text {is }} / \mathrm{S}^{\mathrm{s}}$ & IWP & $\bullet$ \\
\hline $\mathrm{H} / \mathrm{S}^{\mathrm{s}} / \mathrm{SG}$ & IWP & $\bullet$ \\
\hline $\mathrm{H} / \mathrm{S}^{\mathrm{s}}$ & IWP & \\
\hline$S^{s}$ & IWP & \\
\hline$S^{s}$ & IWP & \\
\hline $\mathrm{H} / \mathrm{S}^{\text {is }}$ & IWP & $\bullet$ \\
\hline $\mathrm{H} / \mathrm{S}^{\text {is }}$ & $\mathrm{T}$ & $\bullet$ \\
\hline$S^{s}$ & IWP & \\
\hline$S^{s}$ & IWP & \\
\hline $\mathrm{H} / \mathrm{S}^{\text {is }}$ & IWP & $\bullet$ \\
\hline$S^{s}$ & IWP & $\bullet$ \\
\hline
\end{tabular}




\begin{tabular}{|c|c|c|c|c|}
\hline Taxa & $\begin{array}{l}\text { Habitat } \\
\text { Code }\end{array}$ & $\begin{array}{l}\text { Biogeographic } \\
\text { Region }\end{array}$ & Inshore & Offshore \\
\hline Holothuria michaelseni Erwe, 1913 & $\mathrm{~S}^{\mathrm{is}} / \mathrm{SG}$ & WA & $\bullet$ & \\
\hline Holothuria modesta Ludwig, 1875 & $S^{s}$ & IA/RS & $\bullet$ & \\
\hline Holothuria olivacea Ludwig, 1888 & $\mathrm{~S}^{\mathrm{s}}$ & IWP & & $\bullet$ \\
\hline Holothuria pardalis Selenka, 1867 & $S^{s}$ & IWP & $\bullet$ & $\bullet$ \\
\hline Holothuria pervicax Selenka, 1867 & $\mathrm{H}^{\mathrm{is}}$ & IWP & & $\bullet$ \\
\hline Holothuria rigida (Selenka, 1867) & $\mathrm{H} / \mathrm{S}^{\mathrm{s}}$ & IWP & $\bullet$ & \\
\hline Holothuria scabra Jaeger, 1833 & $S^{\text {is }}$ & IWP & $\bullet$ & $\bullet$ \\
\hline Holothuria spinifera Théel, 1886 & $S^{s}$ & IWP & $\bullet$ & \\
\hline Holothuria verrucosa Selenka, 1867 & $S^{s}$ & IWP & $\bullet$ & \\
\hline Holothuria whitmaei Bell, 1887 & $\mathrm{H} / \mathrm{S}^{\mathrm{s}}$ & $\mathrm{IA} / \mathrm{WP}$ & & $\bullet$ \\
\hline Labidodemas pertinax Ludwig, 1875 & $S^{s}$ & IWP & & $\bullet$ \\
\hline Labidodemas semperianum Selenka, 1867 & $\mathrm{H}^{\mathrm{s}} / \mathrm{S}^{\mathrm{is}}$ & IWP & & $\bullet$ \\
\hline Pearsonothuria graeffei (Semper, 1868) & $\mathrm{H}^{\mathrm{is}}$ & IWP & & • \\
\hline
\end{tabular}

\section{Family: Phyllophoridae}

Havelockia versicolor (Semper, 1868)

$\mathrm{H} / \mathrm{S}^{\mathrm{s}} \quad \mathrm{IWP}$

Hemithyone semperi (Bell, 1884)

$\mathrm{H} / \mathrm{S}^{\mathrm{s}} \quad \mathrm{IWP}$

cf. Phyllophorus sp.nov. ? ${ }^{\mathrm{K}}$

Phyllophorus brocki Ludwig, 1888

Phyllophorus proteus Bell, 1884

Phyllophorus spiculata Chang, 1935

Phyrella sp.

Stolus buccalis (Stimpson, 1855)

Stolus minutus (H.L. Clark, 1938) ${ }^{\mathrm{P}}$

Thyone grisea H.L. Clark, $1938^{\mathrm{P}}$

Thyone micra H.L. Clark, 1938

Thyone papuensis Théel, 1886

H/S

$\mathrm{H}^{\mathrm{s}}$

IA

$\mathrm{H}^{\mathrm{s}}$

$\mathrm{H} / \mathrm{S}$

NA

$\mathrm{U}$

Sis

$\mathrm{H}^{\mathrm{s}}$

$\mathrm{H}^{\text {is }}$

$\mathrm{H}^{\mathrm{s}}$

$\mathrm{H}^{\mathrm{s}}$

IWP

Family: Sclerodactylidae

Afrocucumis africana (Semper, 1868)

Cladolabes aciculus (Semper, 1868)

Cladolabes hamatus (Sluiter, 1914)

Cladolabes schmeltzii (Ludwig, 1875)

\section{Family: Stichopodidae}

Stichopus chloronotus Brandt, 1835

Stichopus ellipes H.L. Clark, $1938^{\mathrm{P}}$

Stichopus hermanni Semper, 1868

Stichopus horrens Selenka, 1867

Stichopus monotuberculatus (Quoy \& Gaimard, 1833)

Stichopus naso Semper, 1868

Stichopus sp. nov.

Thelenota ananas (Jaeger, 1833)

Thelenota anax H.L. Clark, 1921

$\begin{array}{ll}\mathrm{H}^{\text {is }} & \text { IWP } \\ \mathrm{H}^{\mathrm{s}} & \text { IWP } \\ \mathrm{H}^{\mathrm{s}} & \text { IO } \\ \mathrm{H}^{\mathrm{s}} & \text { IWP }\end{array}$

\section{Family: Synaptidae}

Euapta godeffroyi (Semper, 1868)

Leptosynapta latipatina H.L. Clark, 1921

Opheodesoma grisea (Semper, 1868)

Polyplectana kefersteinii (Selenka, 1867)

Protankyra similis (Semper, 1868)

$\mathrm{H}^{\text {is }}$

$\mathrm{S}^{\mathrm{s}}$

$\mathrm{H}^{\mathrm{s}} / \mathrm{S}^{\text {is }}$

$\mathrm{H}^{\mathrm{s}} / \mathrm{S}^{\text {is }}$

$S^{s}$

Ss

U

$\mathrm{H} / \mathrm{S}^{s} \quad$ IWP

$\mathrm{H} / \mathrm{S}^{\mathrm{s}} \quad$ IWP

$S^{\text {is }} \quad$ IP

Sis NA

$\mathrm{H}^{\mathrm{s}} / \mathrm{EZ}^{1}$ WP

$\mathrm{H} / \mathrm{S}^{s} \quad$ IWP

U WP 


\begin{tabular}{llll} 
& Habitat & Biogeographic \\
Taxa & Code & Inshore & Offshore \\
\hline Protankyra sp. nov.1 & $\mathrm{U}$ & & $\bullet$ \\
Protankyra sp. nov.2 & $\mathrm{U}$ & & $\bullet$ \\
Protankyra verrilli (Théel, 1886) & $\mathrm{S}^{\mathrm{s}}$ & $\mathrm{NA}$ & $\bullet$ \\
Rynkatorpa bisperforata (H.L. Clark, 1938) & $\mathrm{S}^{\mathrm{i}}$ & $\mathrm{WA}$ & $\bullet$ \\
Synapta maculata (Chamisso \& Eysenhardt, 1821) & $\mathrm{H}^{\mathrm{P}} \mathrm{S}^{\text {is }}$ & $\mathrm{IWP}$ & \\
Synaptula macra (H.L. Clark, 1938) & $\mathrm{H}^{\mathrm{s}} / \mathrm{EZ}^{1}$ & $\mathrm{IA}$ & $\bullet$ \\
Synaptula recta (Semper, 1868) & $\mathrm{H}^{\mathrm{is}} / \mathrm{EZ}^{1}$ & $\mathrm{IWP}$ & $\bullet$
\end{tabular}

\section{Class: Ophiuroidea}

\section{Family: Amphiuridae}

Amphioplus depressa (Ljungman, 1867)

Amphioplus hastatus (Ljungman, 1867)

Amphioplus ochroleuca (Brock, 1888)

Amphipholis squamata (Delle-Chiaje, 1828)

Amphiura abbreviata Koehler, 1905

Amphiura cf. ambigua Koehler, 1905

Amphiura bidentata H.L. Clark, 1938

Amphiura brachyactis H.L. Clark, 1938

Amphiura catephes H.L. Clark, $1938^{\mathrm{p} * *}$

Amphiura constricta Lyman, 1879

Amphiura leucaspis H.L. Clark, 1938 ${ }^{\mathrm{P}}$

Amphiura microsoma H.L. Clark, 1915

Amphiura octacantha (H.L. Clark, 1915)

Amphiura sp. nov.

Amphiura stictacantha H.L. Clark, $1938^{\mathrm{P}}$

Amphiura tenuis (H.L. Clark, 1938) ${ }^{\mathrm{P}}$

Amphiura velox Koehler, 1910

Dougaloplus sp.

Ophiocentrus aspera (Koehler, 1905)

Ophiocentrus dilatata (Koehler, 1905)

Ophiocentrus verticillatus (Döderlein, 1896)

$\mathrm{H}^{\mathrm{s}}$
$\mathrm{H}^{\mathrm{s}}$
$\mathrm{H}^{\mathrm{s}}$
$\mathrm{H}^{\mathrm{s}}$
$\mathrm{S}^{\mathrm{s}}$
$\mathrm{H}^{\mathrm{s}}$
$\mathrm{H}^{\mathrm{s}}$
$\mathrm{H}^{\mathrm{s}}$
$\mathrm{H}^{\mathrm{i}}$
$\mathrm{H}^{\mathrm{s}}$
$\mathrm{H}^{\mathrm{s}}$
$\mathrm{U}^{\mathrm{s}}$
$\mathrm{S}^{\mathrm{s}}$
$\mathrm{S}^{\mathrm{s}}$
$\mathrm{H}^{\mathrm{s}}$
$\mathrm{S}^{\mathrm{i}}$
$\mathrm{S}^{\mathrm{s}}$
$\mathrm{S}^{\mathrm{s}}$
$\mathrm{S}^{\mathrm{s}}$
$\mathrm{S}^{\mathrm{s}}$
$\mathrm{S}^{\mathrm{s}}$

\section{Family: Euryalidae}

Euryale asperum Lamarck, 1816
$\mathrm{H}^{\mathrm{s}} / \mathrm{EZ}^{5}$
$\mathrm{IA} / \mathrm{IO}$

\section{Family: Gorgonocephalidae}

Astroboa nuda (Lyman, 1874)

$\mathrm{H}^{\mathrm{s}}$

$\mathrm{IA} / \mathrm{IO}$

\section{Family: Ophiactidae}

Ophiactis fuscolineata H.L. Clark, $1938^{\mathrm{P}}$

Ophiactis hemiteles H.L. Clark, 1915

Ophiactis luteomaculata H.L. Clark, 1915

Ophiactis macrolepidota Marktanner-Turneretscher, 1887

Ophiactis modesta Brock, 1888

Ophiactis picteti (de Loriol, 1893)

Ophiactis savignyi (Müller \& Troschel, 1842)

$\begin{array}{ll}\mathrm{H}^{\mathrm{s}} & \mathrm{NA} \\ \mathrm{H}^{\mathrm{s}} & \mathrm{IO} / \mathrm{NA} \\ \mathrm{H}^{\mathrm{s}} & \mathrm{A} \\ \mathrm{H}^{\mathrm{s}} & \text { IWP } \\ \mathrm{H}^{\mathrm{s}} & \mathrm{IWP} \\ \mathrm{U} & \mathrm{IA} / \mathrm{IO} \\ \mathrm{H}^{\mathrm{s}} / \mathrm{EZ}^{1} & \mathrm{~T}\end{array}$

\section{Family: Ophiocomidae}

Ophiarthrum elegans Peters, 1851

Ophiarthrum pictum (Müller \& Troschel, 1842)

$\mathrm{H}^{\text {is }}$

Ophiocoma anaglyptica Ely, 1944

$\mathrm{H}^{\text {is }}$
$\mathrm{H}^{\mathrm{i}}$

IWP

IWP

WP 


\begin{tabular}{|c|c|c|c|c|}
\hline Taxa & $\begin{array}{l}\text { Habitat } \\
\text { Code }\end{array}$ & $\begin{array}{l}\text { Biogeographic } \\
\text { Region }\end{array}$ & Inshore & Offshore \\
\hline Ophiocoma brevipes Peters, 1851 & $S^{i}$ & IWP & & $\bullet$ \\
\hline Ophiocoma dentata Müller \& Troschel, 1842 & $\mathrm{H}^{\mathrm{s}} / \mathrm{S}^{\mathrm{i}}$ & IWP & & $\bullet$ \\
\hline Ophiocoma doederleini de Loriol, 1899 & $\mathrm{H}^{\mathrm{s}}$ & IWP & & $\bullet$ \\
\hline Ophiocoma erinaceus Müller \& Troschel, 1842 & $\mathrm{H}^{\mathrm{s}} / \mathrm{S}^{\mathrm{i}}$ & IWP & & $\bullet$ \\
\hline Ophiocoma pica Müller \& Troschel, 1842 & $\mathrm{H}^{\text {is }} / \mathrm{EZ}^{2}$ & IWP & & $\bullet$ \\
\hline Ophiocoma pusilla (Brock, 1888) & $\mathrm{H}^{\mathrm{s}}$ & $\mathrm{IA} / \mathrm{IO}$ & & $\bullet$ \\
\hline Ophiocoma schoenleinii Müller \& Troschel, 1842 & $\mathrm{H}^{\mathrm{i}}$ & IWP & & $\bullet$ \\
\hline Ophiocoma scolopendrina (Lamarck, 1816) & $\mathrm{H}^{\mathrm{i}}$ & IWP & $\bullet$ & $\bullet$ \\
\hline Ophiocomella sexradia (Duncan, 1887) & $\mathrm{H}^{\mathrm{s}} / \mathrm{EP}$ & IWP & & $\bullet$ \\
\hline Ophiomastix annulosa (Lamarck, 1816) & $\mathrm{H}^{\mathrm{i}}$ & IWP & & $\bullet$ \\
\hline Ophiomastix caryophyllata Lütken, 1869 & $\mathrm{H}^{\mathrm{is}}$ & IWP & $\bullet$ & \\
\hline Ophiomastix mixta Lütken, 1869 & $\mathrm{H}^{\text {is }}$ & WP & $\bullet$ & \\
\hline Ophiomastix palaoensis Murakami, 1943 & $\mathrm{H}^{\mathrm{i}}$ & WP & & $\bullet$ \\
\hline Ophiomastix variabilis Koehler, 1905 & $\mathrm{H}^{\mathrm{is}}$ & IWP & $\bullet$ & $\bullet$ \\
\hline \multicolumn{5}{|l|}{ Family: Ophiodermatidae } \\
\hline Cryptopelta callista H.L. Clark, $1938^{\mathrm{P}}$ & $\mathrm{H}^{\mathrm{s}}$ & NA & $\bullet$ & \\
\hline Cryptopelta granulifera H.L. Clark, 1909 & $\mathrm{H} / \mathrm{S}^{\mathrm{s}}$ & $\mathrm{IO}$ & & $\bullet$ \\
\hline Ophiarachna affinis Lütken, 1869 & $\mathrm{H}^{\mathrm{s}}$ & IWP & & $\bullet$ \\
\hline Ophiarachna delicata (H.L. Clark, 1932) & $\mathrm{H}^{\mathrm{s}}$ & IWP & & $\bullet$ \\
\hline Ophiarachna incrassata (Lamarck, 1816) & $\mathrm{H} / \mathrm{S}^{\mathrm{s}}$ & IWP & & $\bullet$ \\
\hline Ophiarachnella gorgonia (Müller \& Troschel, 1842) & $\mathrm{H}^{\mathrm{is}}$ & IWP & $\bullet$ & $\bullet$ \\
\hline Ophiarachnella infernalis (Müller \& Troschel, 1842) & $\mathrm{H}^{\mathrm{is}}$ & IWP & $\bullet$ & $\bullet$ \\
\hline Ophiarachnella septemspinosa (Müller \& Troschel, 1842) & $\mathrm{H}^{\mathrm{s}}$ & IWP & $\bullet$ & $\bullet$ \\
\hline Ophiarachnella snelliusi (A.H. Clark, 1964) & $\mathrm{H}^{\mathrm{s}}$ & IA & & $\bullet$ \\
\hline Ophiarachnella sphenisci (Bell, 1894) & $\mathrm{H}^{\mathrm{s}}$ & IA & $\bullet$ & \\
\hline Ophiochaeta hirsuta Lütken, 1869 & $\mathrm{H}^{\mathrm{s}}$ & IWP & & $\bullet$ \\
\hline Ophiochasma stellata (Ljungman, 1867) & $S^{s}$ & IA & $\bullet$ & \\
\hline Ophioconis cincta Brock, 1888 & $\mathrm{H}^{\mathrm{s}}$ & $\mathrm{IA} / \mathrm{IO}$ & $\bullet$ & $\bullet$ \\
\hline Ophiodyscrita acosmeta H.L. Clark, 1938 & $\mathrm{H} / \mathrm{S}^{\text {is }}$ & IA & $\bullet$ & \\
\hline Ophiopeza spinosa (Ljungman, 1867) & $\mathrm{H} / \mathrm{S}^{\mathrm{s}}$ & IWP & & $\bullet$ \\
\hline \multicolumn{5}{|l|}{ Family: Ophiolepididae } \\
\hline Ophiolepis cincta Müller \& Troschel, 1842 & $\mathrm{H}^{\mathrm{s}} / \mathrm{S}^{\mathrm{i}} / \mathrm{SG}$ & IWP & & $\bullet$ \\
\hline Ophiolepis irregularis Brock, 1888 & $\mathrm{H} / \mathrm{S}^{\mathrm{s}}$ & IWP & & $\bullet$ \\
\hline Ophiolepis superba H.L. Clark, 1915 & $S^{s}$ & IWP & & $\bullet$ \\
\hline Ophiolepis unicolor H.L. Clark, $1938^{\mathrm{P}}$ & $\mathrm{H} / \mathrm{S}^{\mathrm{s}}$ & NA & $\bullet$ & \\
\hline Ophioplocus giganteus Irimura \& Yoshino, 1999 & $\mathrm{H}^{\mathrm{i}} / \mathrm{S}^{\text {is }}$ & IA & & $\bullet$ \\
\hline Ophioplocus imbricatus (Müller \& Troschel, 1842) & $\mathrm{S}^{\mathrm{i}} / \mathrm{SG}$ & IWP & $\bullet$ & $\bullet$ \\
\hline \multicolumn{5}{|l|}{ Family: Ophiomyxidae } \\
\hline Ophiomyxa australis Lütken, 1869 & $S^{s}$ & IWP & $\bullet$ & $\bullet$ \\
\hline \multicolumn{5}{|l|}{ Family: Ophionereididae } \\
\hline Ophionereis dubia (Müller \& Troschel, 1842) & $\mathrm{H}^{\mathrm{is}} / \mathrm{S}^{\mathrm{s}}$ & IWP & $\bullet$ & $\bullet$ \\
\hline Ophionereis fusca Brock, 1888 & $\mathrm{H}^{\mathrm{s}}$ & WP & & $\bullet$ \\
\hline Ophionereis hexactis Clark H L, 1938 & $\mathrm{H}^{\mathrm{s}}$ & IWP & & $\bullet$ \\
\hline Ophionereis porrecta Lyman, 1860 & $\mathrm{H}^{\mathrm{s}}$ & IWP & & $\bullet$ \\
\hline Ophionereis semoni (Döderlein, 1896) & $\mathrm{H}^{\mathrm{s}}$ & WP & $\bullet$ & \\
\hline
\end{tabular}




\begin{tabular}{|c|c|c|c|c|}
\hline Taxa & $\begin{array}{l}\text { Habitat } \\
\text { Code }\end{array}$ & $\begin{array}{l}\text { Biogeographic } \\
\text { Region }\end{array}$ & Inshore & Offshore \\
\hline \multicolumn{5}{|l|}{ Family: Ophiotrichidae } \\
\hline Lissophiothrix delicata H.L. Clark, $1938^{\mathrm{P}}$ & $\mathrm{H} / \mathrm{S}^{\mathrm{s}}$ & NA & $\bullet$ & \\
\hline Macrophiothrix caenosa Hoggett, 2006 & $\mathrm{H}^{\mathrm{i}} / \mathrm{S}^{\mathrm{is}}$ & IA & $\bullet$ & \\
\hline Macrophiothrix callizona H.L. Clark, 1938 & $\mathrm{H}^{\mathrm{i}} / \mathrm{S}^{\mathrm{is}}$ & WA & $\bullet$ & \\
\hline Macrophiothrix demessa (Lyman, 1861) & $\mathrm{H}^{\text {is }}$ & IWP & & $\bullet$ \\
\hline Macrophiothrix koehleri A.M. Clark, 1968 & $\mathrm{H} / \mathrm{S}^{\mathrm{i}}$ & IA/WP & & $\bullet$ \\
\hline Macrophiothrix leucosticha Hoggett, 1991 & $\mathrm{H}^{\mathrm{is}}$ & IA & & $\bullet$ \\
\hline Macrophiothrix longipeda (Lamarck, 1816) & $\mathrm{H}^{\mathrm{i}} / \mathrm{S}^{\mathrm{is}}$ & IWP & $\bullet$ & $\bullet$ \\
\hline Macrophiothrix lorioli A.M. Clark, 1968 & $\mathrm{H} / \mathrm{S}^{\text {is }}$ & $\mathrm{IA} / \mathrm{WP}$ & & $\bullet$ \\
\hline Macrophiothrix megapoma H.L. Clark, $1938^{\mathrm{P}}$ & $\mathrm{H}^{\mathrm{i}} / \mathrm{S}^{\mathrm{is}}$ & NA & $\bullet$ & \\
\hline Macrophiothrix microplax (Bell, 1884) & $\mathrm{H}^{\mathrm{i}} / \mathrm{S}^{\text {is }}$ & NA & $\bullet$ & \\
\hline Macrophiothrix paucispina Hoggett, 1991 & $\mathrm{H}^{\mathrm{i}} / \mathrm{S}^{\mathrm{is}}$ & NA & $\bullet$ & $\bullet$ \\
\hline Macrophiothrix propinqua (Lyman, 1861) & $\mathrm{H}^{\mathrm{is}}$ & IWP & & $\bullet$ \\
\hline Macrophiothrix rhabdota (H.L. Clark, 1915) & $\mathrm{H}^{\mathrm{is}}$ & NA & & $\bullet$ \\
\hline Macrophiothrix robillardi (de Loriol, 1893) & $\mathrm{H} / \mathrm{S}^{\mathrm{i}}$ & IWP & & $\bullet$ \\
\hline Ophiocnemis marmorata (Lamarck, 1816) & $\mathrm{S}^{\text {is }}$ & $\mathrm{IA} / \mathrm{IO}$ & $\bullet$ & \\
\hline Ophiogymna cf. pellicula (Duncan, 1887) & $\mathrm{H}^{\mathrm{s}} / \mathrm{EZ}^{4}$ & IWP & & $\bullet$ \\
\hline Ophiomaza cacaotica Lyman, 1871 & $\mathrm{H}^{\mathrm{s}} / \mathrm{EZ}^{6}$ & IWP & $\bullet$ & \\
\hline Ophiothela danae Verrill, 1869 & $\mathrm{H}^{\mathrm{s}} / \mathrm{EZ}^{5}$ & IWP & $\bullet$ & $\bullet$ \\
\hline Ophiothrix armata Koehler, 1905 & $\mathrm{H}^{\mathrm{s}} / \mathrm{EZ}^{5}$ & WP & & $\bullet$ \\
\hline Ophiothrix ciliaris (Lamarck, 1816) & $\mathrm{H}^{\mathrm{s}} / \mathrm{EZ}^{1}$ & IA & $\bullet$ & $\bullet$ \\
\hline Ophiothrix contenta Koehler, 1930 & $\mathrm{H}^{\mathrm{s}}$ & IA & $\bullet$ & \\
\hline Ophiothrix deceptor Koehler, 1922 & $\mathrm{H}^{\mathrm{s}}$ & IWP & & $\bullet$ \\
\hline Ophiothrix exigua Lyman, 1874 & $\mathrm{H}^{\mathrm{s}} / \mathrm{EZ}^{1}$ & IWP & $\bullet$ & $\bullet$ \\
\hline Ophiothrix lineocaerulea H.L. Clark, 1928 & $\mathrm{H}^{\mathrm{s}} / \mathrm{EZ}^{1}$ & IA & $\bullet$ & \\
\hline Ophiothrix martensi Lyman, 1874 & $\mathrm{H}^{\mathrm{s}}$ & IA & $\bullet$ & $\bullet$ \\
\hline Ophiothrix melanosticta Grube, 1868 & $\mathrm{H}^{\mathrm{s}}$ & IA & $\bullet$ & \\
\hline Ophiothrix miles Koehler, 1905 & $\mathrm{H}^{\mathrm{s}}$ & WP & • & \\
\hline Ophiothrix nereidina (Lamarck, 1816) & $\mathrm{H}^{\mathrm{s}} / \mathrm{EZ}^{5}$ & IWP & $\bullet$ & $\bullet$ \\
\hline Ophiothrix plana Lyman, 1874 & $\mathrm{H}^{\mathrm{s}}$ & WP & $\bullet$ & \\
\hline Ophiothrix picteti de Loriol, 1893 & $\mathrm{H}^{\mathrm{s}}$ & IA & & $\bullet$ \\
\hline Ophiothrix purpurea von Martens, 1867 & $\mathrm{H}^{\mathrm{s}} / \mathrm{EZ}^{5}$ & IWP & & $\bullet$ \\
\hline Ophiothrix savignyi (Müller \& Troschel, 1842) & $\mathrm{H}^{\mathrm{s}}$ & IWP & & $\bullet$ \\
\hline Ophiothrix smaragdina Studer, 1882 & $\mathrm{H}^{\mathrm{s}} / \mathrm{EZ}^{1}$ & NA & $\bullet$ & \\
\hline Ophiothrix (Placophiothrix) striolata Grube, 1868 & $S^{s}$ & $\mathrm{IP}$ & $\bullet^{\mathrm{K}}$ & \\
\hline Ophiothrix trilineata Lütken, 1869 & $\mathrm{H}^{\mathrm{s}}$ & IWP & $\bullet$ & $\bullet$ \\
\hline \multicolumn{5}{|l|}{ Family: Ophiuridae } \\
\hline Dictenophiura stellata (Studer, 1882) & $S^{s}$ & IA & $\bullet$ & \\
\hline Ophiura kinbergi (Ljungman, 1866) & $S^{s}$ & IWP & $\bullet$ & \\
\hline
\end{tabular}


APPENDIX 3 Species and family richness, number of collecting events, and family occurrence at each location within the Project Area.

\begin{tabular}{|c|c|c|c|c|}
\hline Location & Collecting Year Range & Species Richness & No. Collecting Events & No. Families \\
\hline Adele Island & $1962-1990$ & 4 & 2 & 3 \\
\hline Admiral Island & 1989 & 4 & 1 & 1 \\
\hline Admiralty Gulf & 1978 & 4 & 2 & 4 \\
\hline Albert Islands & 1988 & 1 & 1 & 1 \\
\hline Ashmore Reef ${ }^{\mathrm{OA}}$ & 1978-2002 & 173 & 8 & 36 \\
\hline Augustus Island & 1933-1990 & 26 & 5 & 17 \\
\hline Beagle Bay & 1932-1988 & 4 & 2 & 4 \\
\hline Beagle Reef & 1991 & 8 & 1 & 7 \\
\hline Bedford Island & 1989 & 6 & 1 & 5 \\
\hline Bigge Island & 1987 & 1 & 1 & 1 \\
\hline Broome & 1913-2006 & 167 & 41 & 41 \\
\hline Buffon Island & 1983-1988 & 4 & 2 & 3 \\
\hline Caffarelli Island & 1994 & 2 & 1 & 2 \\
\hline Cambridge Gulf & 1995 & 1 & 1 & 1 \\
\hline Camden Sound & 1987-1990 & 10 & 2 & 10 \\
\hline Cape Bossut & 1929-1985 & 15 & 5 & 12 \\
\hline Cape Frezier & 1980 & 2 & 1 & 2 \\
\hline Cape Jaubert & - & 2 & 1 & 2 \\
\hline Cape Leveque & 1972-1988 & 18 & 4 & 9 \\
\hline Cape Villaret & 1929 & 2 & 2 & 2 \\
\hline Cape Voltaire & 1976 & 7 & 1 & 6 \\
\hline Careening Bay & 1987 & 1 & 1 & 1 \\
\hline Cartier Island ${ }^{\mathrm{OA}}$ & 1977-1992 & 56 & 3 & 23 \\
\hline Cassini Island & 1991-1998 & 17 & 4 & 12 \\
\hline Churchill Reef & 1991 & 8 & 1 & 6 \\
\hline Clerke Reef ${ }^{\mathrm{OA}}$ & 1982 & 63 & 1 & 21 \\
\hline Cockatoo Island & 1962-1998 & 21 & 7 & 15 \\
\hline Condillac Island & 1976-1991 & 4 & 2 & 3 \\
\hline Corneille Island & 1976 & 1 & 1 & 1 \\
\hline Coulomb Point & 1975-2009 & 6 & 2 & 6 \\
\hline Cygnet Bay & 1975 & 1 & 1 & 1 \\
\hline Derby & 1974 & 2 & 2 & 2 \\
\hline Entrance Island & 1988 & 4 & 1 & 3 \\
\hline False Cape Bossut & 1929-1946 & 6 & 3 & 5 \\
\hline Fenelon Island & 1988 & 2 & 1 & 2 \\
\hline Gourdon Bay & 1962 & 1 & 1 & 1 \\
\hline Hale Island & 1991 & 14 & 1 & 8 \\
\hline Hibernia Reef ${ }^{\mathrm{OA}}$ & 1991-1998 & 24 & 3 & 10 \\
\hline Heritage Reef & 1991 & 5 & 1 & 5 \\
\hline James Price Point & 1988-2009 & 17 & 2 & 10 \\
\hline Jar Island & 1995 & 2 & 1 & 2 \\
\hline Johnson Bank ${ }^{\mathrm{OA}}$ & 2002 & 4 & 1 & 2 \\
\hline Jones Island & 1991-1995 & 11 & 2 & 8 \\
\hline Kalumburu & 1960 & 1 & 1 & 1 \\
\hline King Sound & 1929 & 2 & 2 & 2 \\
\hline
\end{tabular}




\begin{tabular}{|c|c|c|c|c|}
\hline Location & Collecting Year Range & Species Richness & No. Collecting Events & No. Families \\
\hline Kingfisher Island & 1990 & 1 & 1 & 1 \\
\hline Kuri Bay & 1964-1991 & 11 & 4 & 7 \\
\hline Lacepede Islands & 1962-1991 & 22 & 6 & 16 \\
\hline Lacrosse Island & 1995 & 1 & 1 & 1 \\
\hline Lagrange Bay & 1929-1985 & 7 & 4 & 7 \\
\hline Langgi & 1988 & 3 & 1 & 3 \\
\hline Leonie Island & 1994 & 3 & 1 & 2 \\
\hline Lesueur Island & 1991 & 9 & 1 & 5 \\
\hline Long Reef & 1988-1991 & 9 & 2 & 8 \\
\hline Lord Island & 1991 & 5 & 1 & 4 \\
\hline Louis Islands & 1995 & 1 & 1 & 1 \\
\hline Lucas Island & 1988 & 2 & 1 & 2 \\
\hline Macleay Island & 1989 & 6 & 1 & 5 \\
\hline Mary Island & 1989 & 3 & 1 & 1 \\
\hline Mermaid Island & 1991-1994 & 5 & 2 & 3 \\
\hline Mermaid Reef ${ }^{\mathrm{OA}}$ & 1978-2006 & 71 & 3 & 22 \\
\hline Mitchell River & 1968-1977 & 2 & 2 & 2 \\
\hline Montalivet Islands & 1963-1991 & 11 & 5 & 8 \\
\hline Montgomery Reef & 1987-1994 & 19 & 4 & 14 \\
\hline Napier Broome Bay & 1991 & 9 & 1 & 8 \\
\hline One Arm Point & 1975-1988 & 26 & 4 & 13 \\
\hline Parry Harbour & 1991 & 11 & 1 & 9 \\
\hline Pender Bay & 1974 & 6 & 2 & 3 \\
\hline Port Warrender & 1976 & 3 & 2 & 3 \\
\hline Powerful Island & 1991 & 6 & 1 & 5 \\
\hline Prince Frederick Harbour & 1987-1997 & 4 & 3 & 3 \\
\hline Prince Regent River & 1978 & 1 & 1 & 1 \\
\hline Quondong Point & 1975 & 12 & 1 & 7 \\
\hline Robroy Reefs & 1988-1991 & 5 & 2 & 4 \\
\hline Scorpion Island & 1991 & 14 & 2 & 9 \\
\hline Scott $\operatorname{Reef}^{\mathrm{OA}}$ & 1984-2006 & 125 & 3 & 36 \\
\hline Seringapatam Reef ${ }^{\mathrm{OA}}$ & 1978-2006 & 41 & 4 & 18 \\
\hline Sheep Island & 1987 & 1 & 1 & 1 \\
\hline Shirley Island & 1988 & 1 & 1 & 1 \\
\hline Solem Islands & 1991 & 8 & 1 & 5 \\
\hline Storr Island & 1990 & 4 & 1 & 4 \\
\hline Sunday Island & 1991-1994 & 21 & 2 & 11 \\
\hline Tallon Island & 1994 & 7 & 1 & 4 \\
\hline Troughton Island & 1971 & 1 & 1 & 1 \\
\hline Vansittart Bay & 1971-1991 & 2 & 2 & 2 \\
\hline Wailgwin Island & 1988-1990 & 9 & 2 & 5 \\
\hline Walsh Point & 1976 & 12 & 2 & 6 \\
\hline West Governor Island & 1995 & 2 & 1 & 2 \\
\hline Whirlpool Pass & 1994 & 11 & 1 & 8 \\
\hline Woodward Island & 1991 & 2 & 1 & 2 \\
\hline Yampi Sound & 1958-1959 & 11 & 6 & 9 \\
\hline Yankawingarri Island & 1991 & 9 & 1 & 6 \\
\hline York Sound & 1975 & 2 & 1 & 2 \\
\hline
\end{tabular}


CLASS: ASTEROIDEA

\begin{tabular}{|c|c|c|c|c|c|c|c|c|c|c|c|c|}
\hline Location & $\begin{array}{l}\text { Collecting } \\
\text { Year Range }\end{array}$ & 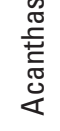 & 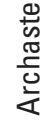 & 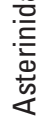 & 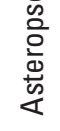 & 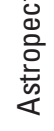 & 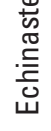 & 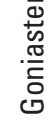 & 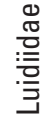 & 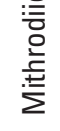 & 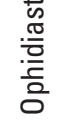 & 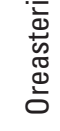 \\
\hline Adele Island & $1962-1990$ & & & & & & & & & & $\bullet$ & \\
\hline Admiral Island & 1989 & & & & & & & & & & & \\
\hline Admiralty Gulf & 1978 & & & & & & & & $\bullet$ & & & \\
\hline Albert Islands & 1988 & & & & & & & & & & & \\
\hline Ashmore Reef ${ }^{\mathrm{OA}}$ & 1978-2002 & $\bullet$ & $\bullet$ & $\bullet$ & $\bullet$ & & $\bullet$ & & & $\bullet$ & $\bullet$ & $\bullet$ \\
\hline Augustus Island & 1933-1990 & & & & & & & & & & & $\bullet$ \\
\hline Beagle Bay & 1932-1988 & & & & & & & & $\bullet$ & & & \\
\hline Beagle Reef & 1991 & & & & & & & & & & & \\
\hline Bedford Island & 1989 & & & $\bullet$ & & & & & & & & \\
\hline Bigge Island & 1987 & & & & & & & & & & & \\
\hline Broome & 1913-2006 & & $\bullet$ & $\bullet$ & & $\bullet$ & $\bullet$ & $\bullet$ & $\bullet$ & & $\bullet$ & $\bullet$ \\
\hline Buffon Island & 1983-1988 & & & & & & & $\bullet$ & & & $\bullet$ & \\
\hline Caffarelli Island & 1994 & & & & & & & & & & & \\
\hline Cambridge Gulf & 1995 & & & & & & & & & & & \\
\hline Camden Sound & 1987-1990 & & & & & & & & & & & \\
\hline Cape Bossut & 1929-1985 & & & & & & & $\bullet$ & & & & $\bullet$ \\
\hline Cape Frezier & 1980 & & & & & & & & & & & \\
\hline Cape Jaubert & - & & & & & & & & & & & \\
\hline Cape Leveque & 1972-1988 & & & $\bullet$ & & & & & & & & \\
\hline Cape Villaret & 1929 & & & & & & & & & & & \\
\hline Cape Voltaire & 1976 & & & & & & & & & & & $\bullet$ \\
\hline Careening Bay & 1987 & & & & & & & & & & & \\
\hline Cartier Island $\mathrm{OA}^{\mathrm{A}}$ & 1977-1992 & & & $\bullet$ & $\bullet$ & & & & & & $\bullet$ & \\
\hline Cassini Island & 1991-1998 & $\bullet$ & & & & & & $\bullet$ & & & $\bullet$ & $\bullet$ \\
\hline Churchill Reef & 1991 & & & & & & & & & & $\bullet$ & \\
\hline Clerke Reef ${ }^{\mathrm{OA}}$ & 1982 & & & & $\bullet$ & & $\bullet$ & & & & $\bullet$ & $\bullet$ \\
\hline Cockatoo Island & 1962-1998 & & & $\bullet$ & & & & & & & $\bullet$ & $\bullet$ \\
\hline Condillac Island & 1976-1991 & & & & & & & & & & & \\
\hline Corneille Island & 1976 & & & & & & & & & & & \\
\hline Coulomb Point & 1975-2009 & & & & & & & & & & & $\bullet$ \\
\hline Cygnet Bay & 1975 & & & & & & & & & & & \\
\hline Derby & 1974 & & & & & & & & & & & \\
\hline Entrance Island & 1988 & & & & & & & & & & & \\
\hline False Cape Bossut & 1929-1946 & & & & & & & & & & & $\bullet$ \\
\hline Fenelon Island & 1988 & & & & & & & & & & & \\
\hline Gourdon Bay & 1962 & & & & & & & & & & & \\
\hline Hale Island & 1991 & & & & & & & & & & & $\bullet$ \\
\hline Hibernia Reef $\mathrm{OA}$ & 1991-1998 & & & & & & & & & & $\bullet$ & $\bullet$ \\
\hline Heritage Reef & 1991 & & & & & & & & & & & \\
\hline James Price Point & 1988-2009 & & & & & & & & & & & \\
\hline Jar Island & 1995 & & & & & & & & & & & \\
\hline Johnson Bank ${ }^{\mathrm{OA}}$ & 2002 & & & & & & $\bullet$ & & & & & \\
\hline Jones Island & 1991-1995 & & & & & & & & & & & \\
\hline Kalumburu & 1960 & & & & & $\bullet$ & & & & & & \\
\hline King Sound & 1929 & & & & & & & $\bullet$ & & & & \\
\hline Kingfisher Island & 1990 & & & & & & & & & & & \\
\hline Kuri Bay & 1964-1991 & & & & & & & & & & & $\bullet$ \\
\hline
\end{tabular}


CLASS: ASTEROIDEA

\begin{tabular}{|c|c|c|c|c|c|c|c|c|c|c|c|c|}
\hline Location & $\begin{array}{l}\text { Collecting } \\
\text { Year Range }\end{array}$ & 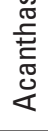 & 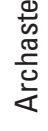 & 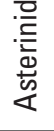 & 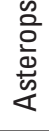 & 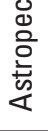 & 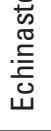 & 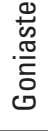 & 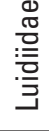 & 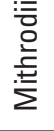 & 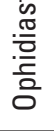 & 这 \\
\hline Lacepede Islands & 1962-1991 & & & & & & & & & & & $\bullet$ \\
\hline Lacrosse Island & 1995 & & & & & & & & & & & \\
\hline Lagrange Bay & 1929-1985 & & $\bullet$ & & & & & & & & & \\
\hline Langgi & 1988 & & & $\bullet$ & & & & & & & & \\
\hline Leonie Island & 1994 & & & & & & & & & & & \\
\hline Lesueur Island & 1991 & & & & & & & & & & & $\bullet$ \\
\hline Long Reef & 1988-1991 & & & $\bullet$ & & & & & & & & $\bullet$ \\
\hline Lord Island & 1991 & & & & & & & & & & & $\bullet$ \\
\hline Louis Islands & 1995 & & & & & & & & & & & \\
\hline Lucas Island & 1988 & & & & & & & $\bullet$ & & & & \\
\hline Macleay Island & 1989 & & & & & & & & & & & $\bullet$ \\
\hline Mary Island & 1989 & & & & & & & & & & & \\
\hline Mermaid Island & 1991-1994 & & & & & & & & & & & \\
\hline Mermaid Reef ${ }^{\mathrm{OA}}$ & 1978-2006 & & & $\bullet$ & & & $\bullet$ & & & & $\bullet$ & $\bullet$ \\
\hline Mitchell River & 1968-1977 & & & & & & & & & & & \\
\hline Montalivet Islands & 1963-1991 & $\bullet$ & & & & & & & & & & $\bullet$ \\
\hline Montgomery Reef & 1987-1994 & & & & & $\bullet$ & & & & & & $\bullet$ \\
\hline Napier Broome Bay & 1991 & & & $\bullet$ & & & & & & & & \\
\hline One Arm Point & 1975-1988 & & & $\bullet$ & & & & & & & & $\bullet$ \\
\hline Parry Harbour & 1991 & & & $\bullet$ & & $\bullet$ & & & & & & \\
\hline Pender Bay & 1974 & & & & & & $\bullet$ & & & & $\bullet$ & $\bullet$ \\
\hline Port Warrender & 1976 & & & & & & & & & & & $\bullet$ \\
\hline Powerful Island & 1991 & & & & & & & & & & & \\
\hline Prince Frederick Harbour & 1987-1997 & & & & & & & & & & & \\
\hline Prince Regent River & 1978 & & & & & & & & & & & $\bullet$ \\
\hline Quondong Point & 1975 & & & & & & & & & & & \\
\hline Robroy Reefs & 1988-1991 & & & & & & & & & & & \\
\hline Scorpion Island & 1991 & & & & & & & & & & & \\
\hline Scott Reef ${ }^{O A}$ & 1984-2006 & $\bullet$ & & $\bullet$ & $\bullet$ & & $\bullet$ & & & $\bullet$ & $\bullet$ & $\bullet$ \\
\hline Seringapatam Reef $\mathrm{OA}$ & 1978-2006 & & & $\bullet$ & $\bullet$ & & $\bullet$ & & & & $\bullet$ & $\bullet$ \\
\hline Sheep Island & 1987 & & & & & & & & & & & \\
\hline Shirley Island & 1988 & & & & & & & & & & & \\
\hline Solem Islands & 1991 & & & & & & & & & & & $\bullet$ \\
\hline Storr Island & 1990 & & & $\bullet$ & & & & & & & & \\
\hline Sunday Island & 1991-1994 & & & & & & & & & & & $\bullet$ \\
\hline Tallon Island & 1994 & & & & & & & & & & & \\
\hline Troughton Island & 1971 & & & & & & & & & & & $\bullet$ \\
\hline Vansittart Bay & 1971-1991 & & & & & $\bullet$ & & & & & & \\
\hline Wailgwin Island & 1988-1990 & & & $\bullet$ & & & & & & & & \\
\hline Walsh Point & 1976 & & & $\bullet$ & & & & & & & & $\bullet$ \\
\hline West Governor Island & 1995 & & & & & & & & & & & \\
\hline Whirlpool Pass & 1994 & & & & & & & & & & & $\bullet$ \\
\hline Woodward Island & 1991 & & & & & & & & & & & \\
\hline Yampi Sound & 1958-1959 & & & $\bullet$ & & & & & & & & $\bullet$ \\
\hline Yankawingarri Island & 1991 & $\bullet$ & & & & & & & & & & \\
\hline York Sound & 1975 & & & & & & & & & & & \\
\hline Total & & & 3 & 18 & 5 & 5 & 7 & 6 & 3 & 2 & 14 & 33 \\
\hline
\end{tabular}




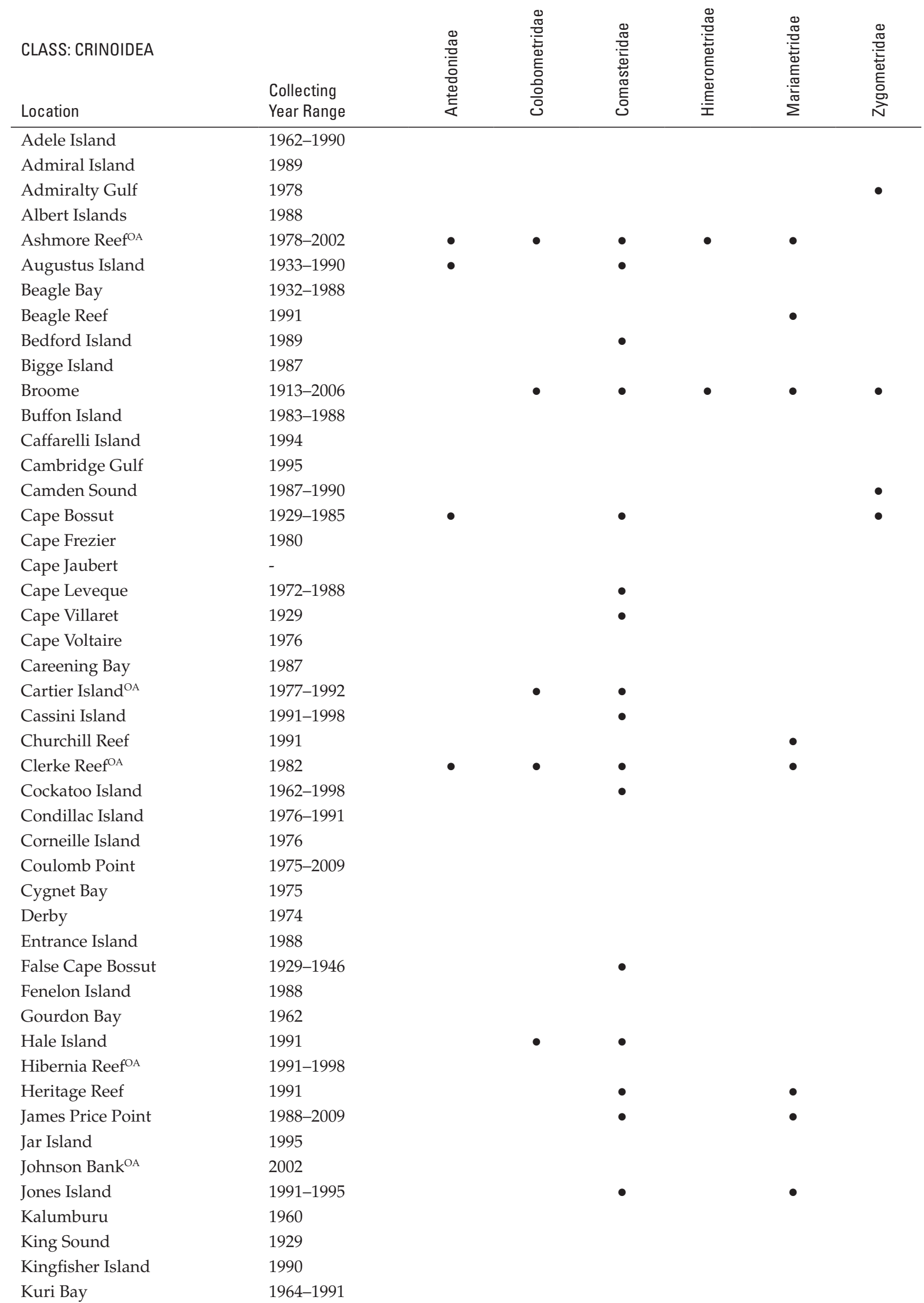




\begin{tabular}{|c|c|c|c|c|c|c|c|}
\hline CLASS: CRINOIDEA & $\begin{array}{l}\text { Collecting } \\
\text { Year Range }\end{array}$ & 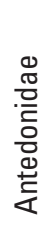 & 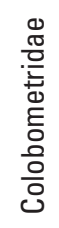 & 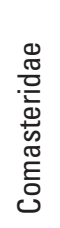 & 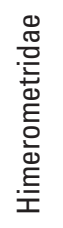 & 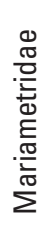 & 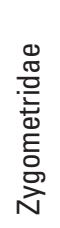 \\
\hline Lacepede Islands & $1962-1991$ & & & $\bullet$ & & $\bullet$ & $\bullet$ \\
\hline Lacrosse Island & 1995 & & & & & & \\
\hline Lagrange Bay & 1929-1985 & & & & & & \\
\hline Langgi & 1988 & & & & & & \\
\hline Leonie Island & 1994 & & & & & & \\
\hline Lesueur Island & 1991 & & & & & & \\
\hline Long Reef & 1988-1991 & & & $\bullet$ & & $\bullet$ & \\
\hline Lord Island & 1991 & & & & & & \\
\hline Louis Islands & 1995 & & & & & & \\
\hline Lucas Island & 1988 & & & & & & \\
\hline Macleay Island & 1989 & & & $\bullet$ & & & \\
\hline Mary Island & 1989 & & & & & & \\
\hline Mermaid Island & 1991-1994 & & & & & & \\
\hline Mermaid Reef $\mathrm{OA}$ & 1978-2006 & & & $\bullet$ & & $\bullet$ & \\
\hline Mitchell River & 1968-1977 & & & & & & \\
\hline Montalivet Islands & 1963-1991 & & & & & & \\
\hline Montgomery Reef & 1987-1994 & & & - & & - & \\
\hline Napier Broome Bay & 1991 & & & & & & \\
\hline One Arm Point & 1975-1988 & & & $\bullet$ & & & \\
\hline Parry Harbour & 1991 & & & & & & \\
\hline Pender Bay & 1974 & & & & & & \\
\hline Port Warrender & 1976 & $\bullet$ & & & & & \\
\hline Powerful Island & 1991 & & & $\bullet$ & & - & \\
\hline Prince Frederick Harbour & 1987-1997 & & & & & & \\
\hline Prince Regent River & 1978 & & & & & & \\
\hline Quondong Point & 1975 & & & $\bullet$ & & & \\
\hline Robroy Reefs & 1988-1991 & & & & & & \\
\hline Scorpion Island & 1991 & & & $\bullet$ & & - & \\
\hline Scott Reef ${ }^{\mathrm{OA}}$ & 1984-2006 & $\bullet$ & - & - & & $\bullet$ & \\
\hline Seringapatam Reef ${ }^{\mathrm{OA}}$ & 1978-2006 & & & & & & \\
\hline Sheep Island & 1987 & & & & & & \\
\hline Shirley Island & 1988 & & & & & & \\
\hline Solem Islands & 1991 & & & $\bullet$ & & $\bullet$ & \\
\hline Storr Island & 1990 & & & & & & \\
\hline Sunday Island & 1991-1994 & & & $\bullet$ & & $\bullet$ & \\
\hline Tallon Island & 1994 & & & & & & \\
\hline Troughton Island & 1971 & & & & & & \\
\hline Vansittart Bay & 1971-1991 & & & & & & \\
\hline Wailgwin Island & 1988-1990 & & & & & & \\
\hline Walsh Point & 1976 & & & & & & \\
\hline West Governor Island & 1995 & & & & & & \\
\hline Whirlpool Pass & 1994 & & & $\bullet$ & & & \\
\hline Woodward Island & 1991 & & & & & & \\
\hline Yampi Sound & 1958-1959 & & & $\bullet$ & & & \\
\hline Yankawingarri Island & 1991 & & & $\bullet$ & & & \\
\hline York Sound & 1975 & & & & & & \\
\hline Total & & 6 & 6 & 3 & 2 & 17 & 5 \\
\hline
\end{tabular}




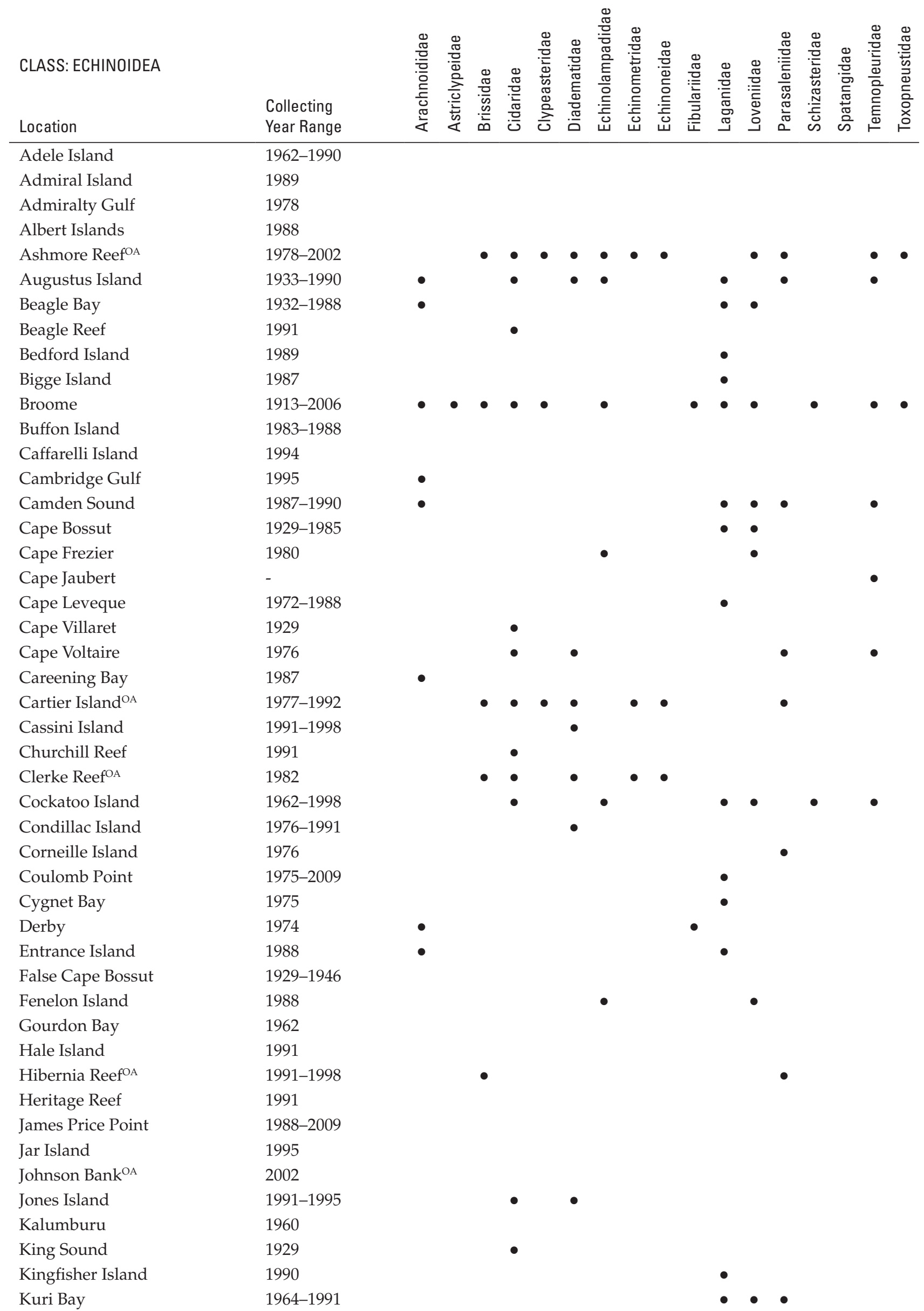




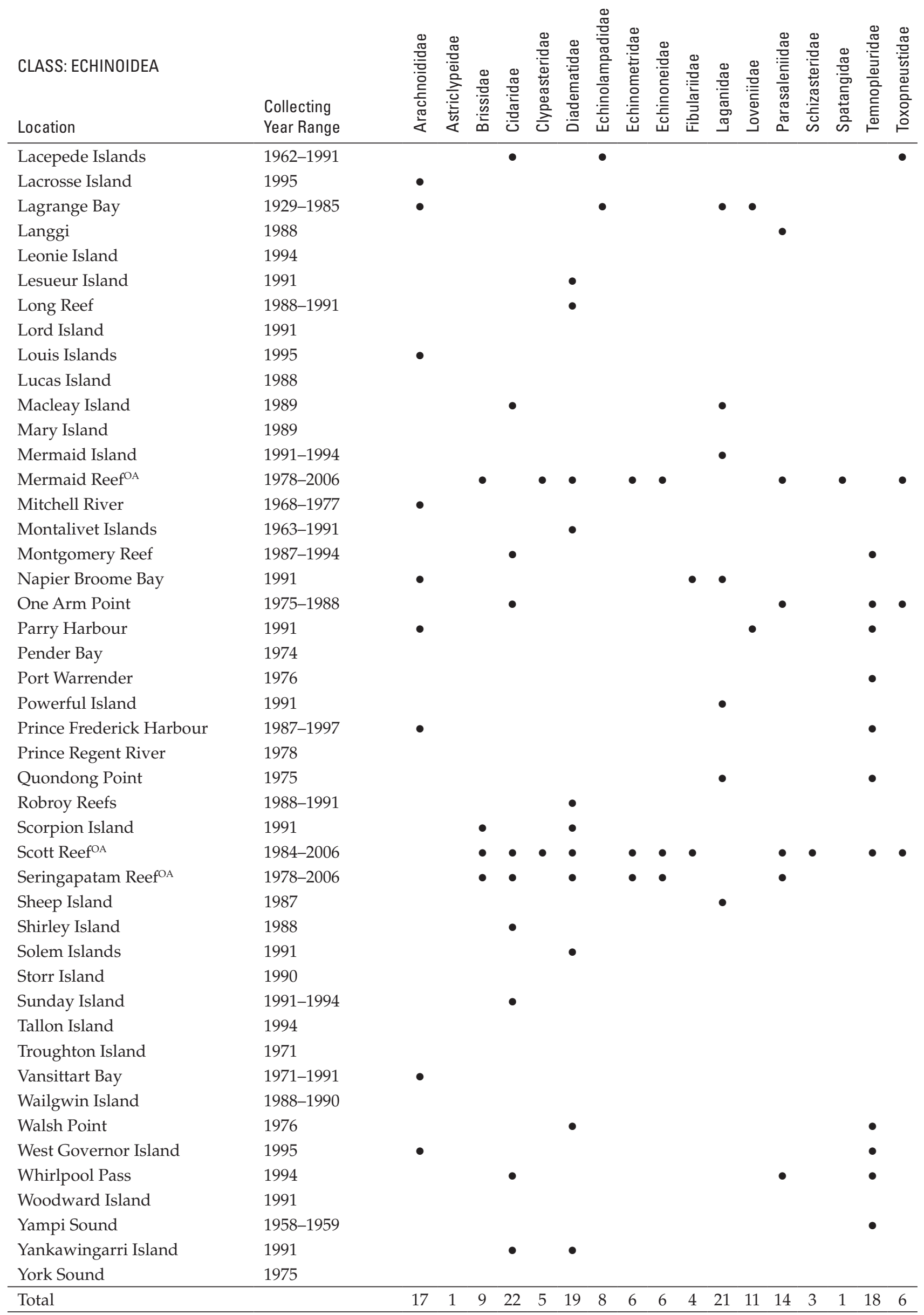


CLASS: HOLOTHUROIDEA

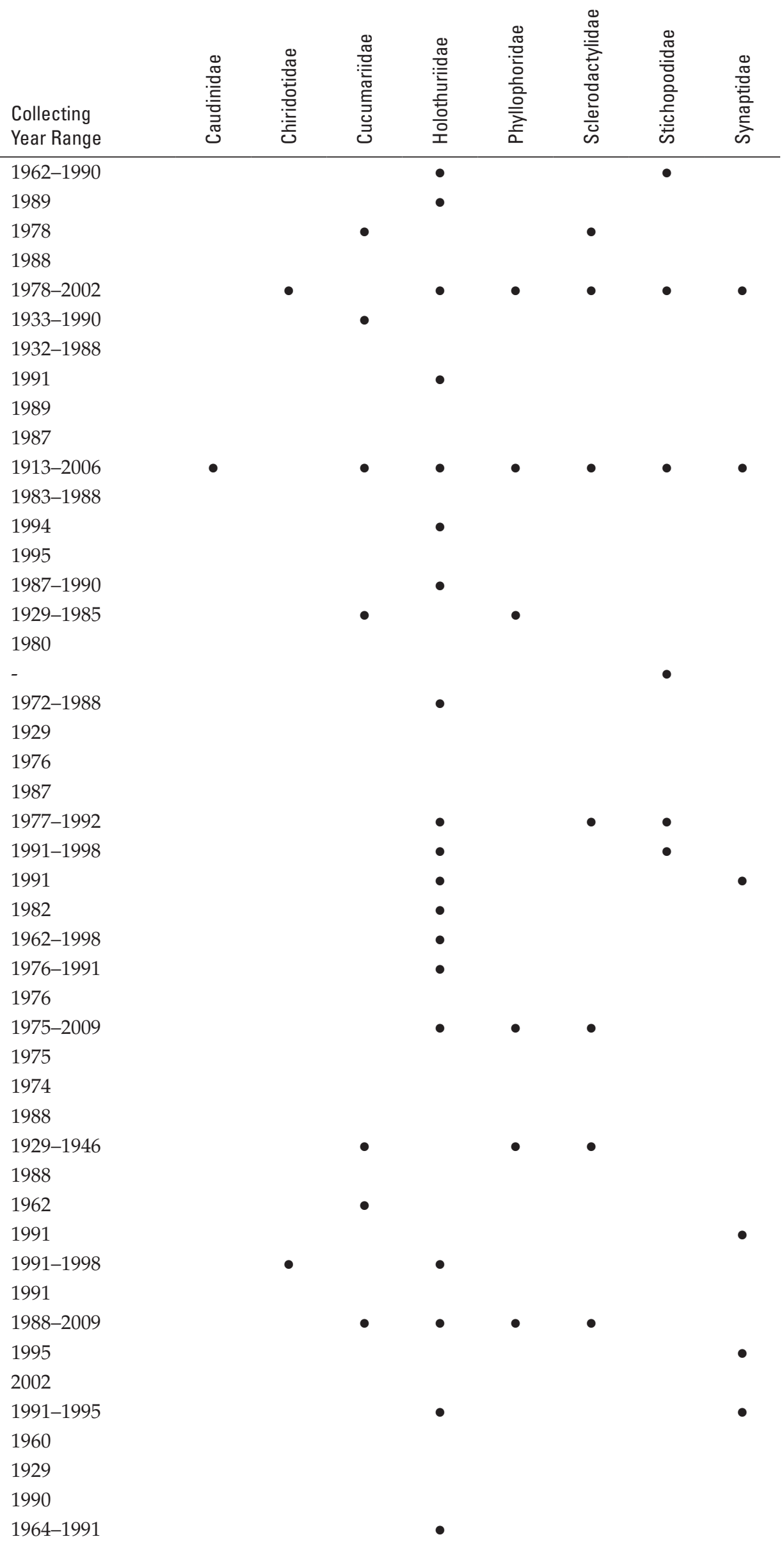


CLASS: HOLOTHUROIDEA

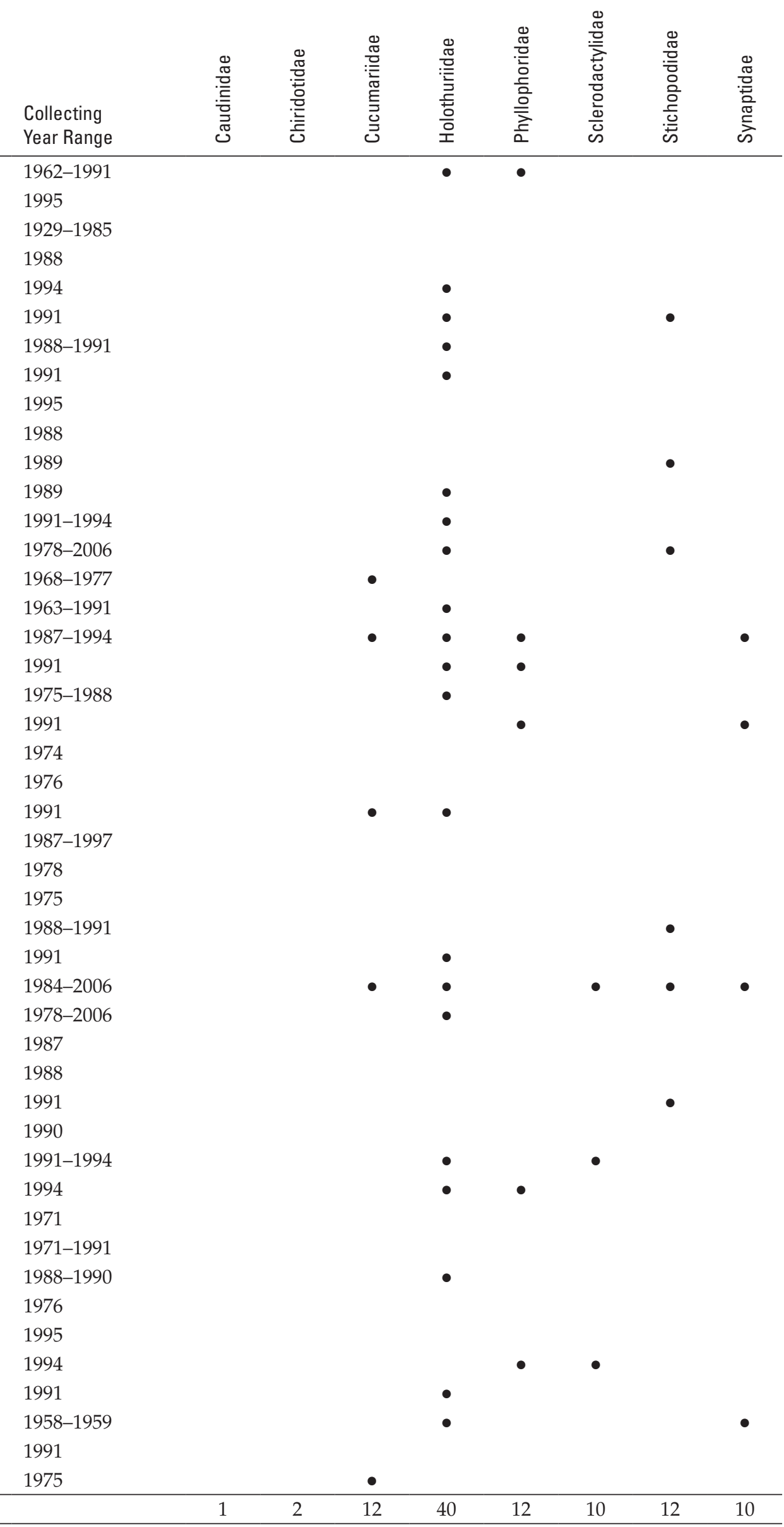




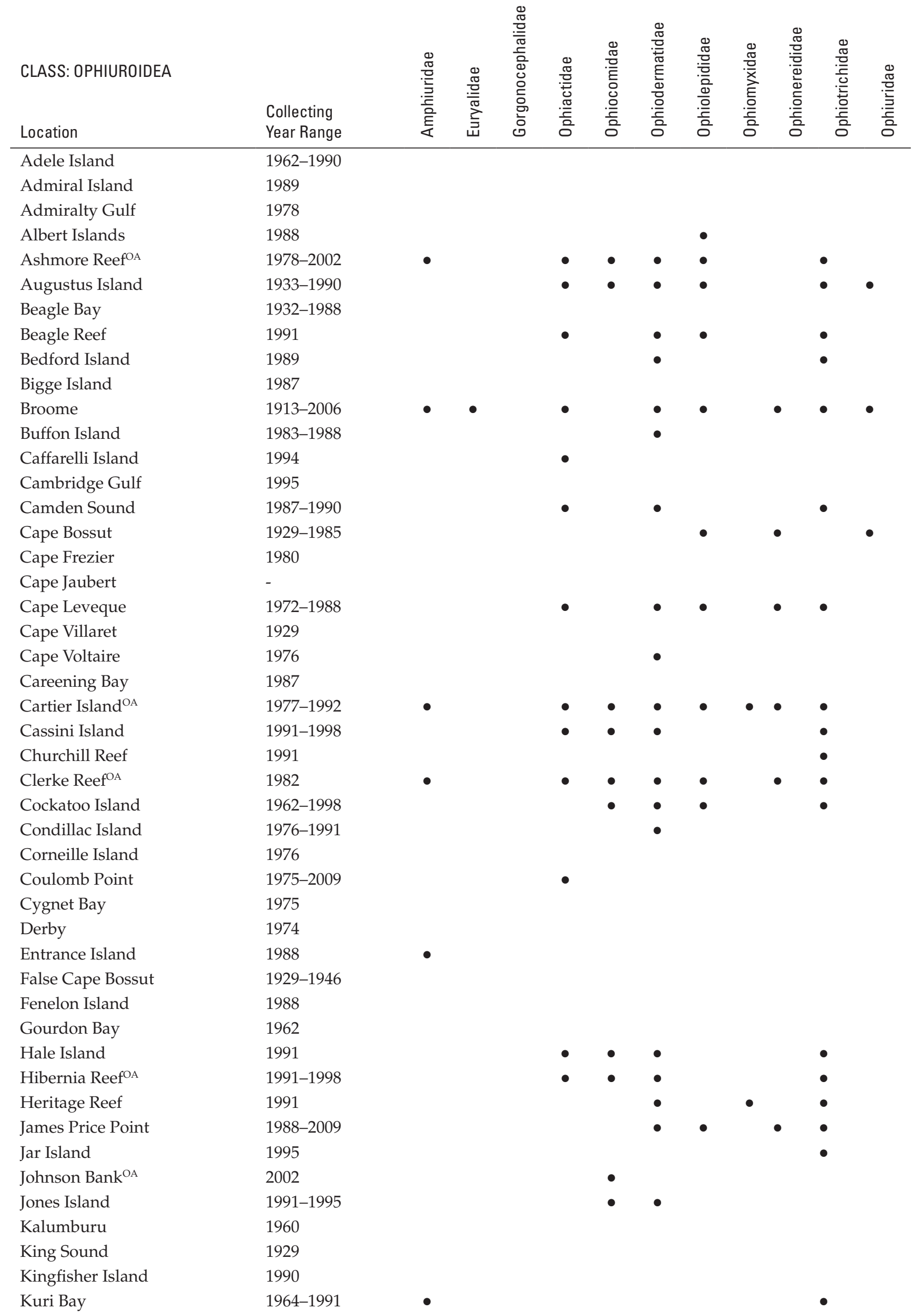




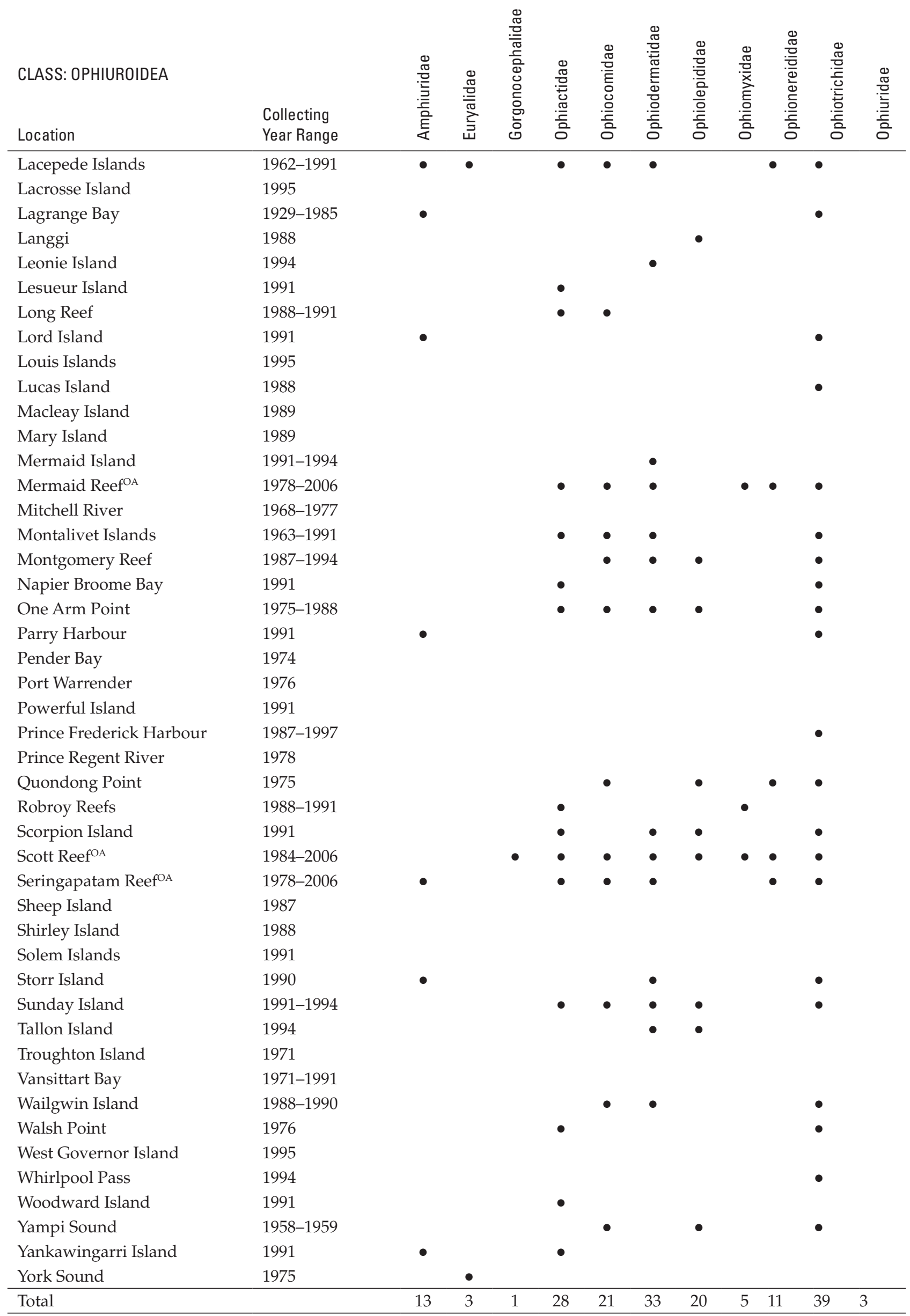

